\title{
Hygroscopicity of secondary organic aerosols formed by oxidation of cycloalkenes, monoterpenes, sesquiterpenes, and related compounds
}

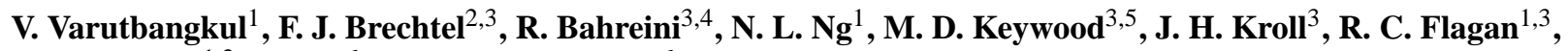 \\ J. H. Seinfeld ${ }^{1,3}$, A. Lee $^{6}$, and A. H. Goldstein ${ }^{6}$ \\ ${ }^{1}$ Department of Chemical Engineering, California Institute of Technology, Pasadena, CA, USA \\ ${ }^{2}$ Brechtel Manufacturing Inc., Hayward, CA, USA \\ ${ }^{3}$ Department of Environmental Science and Engineering, California Institute of Technology, Pasadena, CA, USA \\ ${ }^{4}$ National Oceanic and Atmospheric Administration (NOAA), Boulder, CO, USA \\ ${ }^{5}$ Commonwealth Scientific and Industrial Research Organisation, Melbourne, Australia \\ ${ }^{6}$ Department of Environmental Science, Policy and Management, University of California, Berkeley, CA, USA
}

Received: 14 December 2005 - Published in Atmos. Chem. Phys. Discuss.: 9 February 2006

Revised: 21 April 2006 - Accepted: 5 May 2006 - Published: 29 June 2006

\begin{abstract}
A series of experiments has been conducted in the Caltech indoor smog chamber facility to investigate the water uptake properties of aerosol formed by oxidation of various organic precursors. Secondary organic aerosol (SOA) from simple and substituted cycloalkenes $\left(\mathrm{C}_{5}-\mathrm{C}_{8}\right)$ is produced in dark ozonolysis experiments in a dry chamber $(R H \sim 5 \%)$. Biogenic SOA from monoterpenes, sesquiterpenes, and oxygenated terpenes is formed by photooxidation in a humid chamber $(\sim 50 \% R H)$. Using the hygroscopicity tandem differential mobility analyzer (HTDMA), we measure the diameter-based hygroscopic growth factor $(G F)$ of the SOA as a function of time and relative humidity. All SOA studied is found to be slightly hygroscopic, with smaller water uptake than that of typical inorganic aerosol substances. The aerosol water uptake increases with time early in the experiments for the cycloalkene SOA, but decreases with time for the sesquiterpene SOA. This behavior could indicate competing effects between the formation of more highly oxidized polar compounds (more hygroscopic), and formation of longer-chained oligomers (less hygroscopic). All SOA also exhibit a smooth water uptake with $R H$ with no deliquescence or efflorescence. The water uptake curves are found to be fitted well with an empirical three-parameter functional form. The measured pure organic $G F$ values at $85 \% R H$ are between $1.09-1.16$ for SOA from ozonolysis of cycloalkenes, 1.01-1.04 for sesquiterpene photooxidation SOA, and 1.06-1.10 for the monoterpene and oxygenated terpene SOA. The $G F$ of pure SOA $\left(G F_{\text {org }}\right)$ in experiments in which inorganic seed aerosol is used is determined by assuming volume-weighted water uptake (Zdanovskii-StokesRobinson or "ZSR" approach) and using the size-resolved
\end{abstract}

Correspondence to: J. H. Seinfeld

(seinfeld@caltech.edu) organic mass fraction measured by the Aerodyne Aerosol Mass Spectrometer. Knowing the water content associated with the inorganic fraction yields $G F_{\text {org }}$ values. However, for each precursor, the $G F_{\text {org }}$ values computed from different HTDMA-classified diameters agree with each other to varying degrees. Comparing growth factors from different precursors, we find that $G F_{\text {org }}$ is inversely proportional to the precursor molecular weight and SOA yield, which is likely a result of the fact that higher-molecular weight precursors tend to produce larger and less hygroscopic oxidation products.

\section{Introduction}

The ability of atmospheric aerosol to absorb water is a property with far-reaching implications. Water uptake affects the particle size and phase and therefore influences many physicochemical characteristics of the aerosol, including respiratory tract deposition (Finlay et al., 1997; Broday and Georgopoulos, 2001; Chan et al., 2002), optical properties (Heintzenberg et al., 2001), atmospheric lifetime, and chemical reactivity, especially with respect to heterogeneous chemistry. In addition, the hygroscopic behavior of a particle also determines its ability to serve as a cloud condensation nucleus (CCN). Changes in aerosol water uptake behavior can therefore lead to changes in both direct and indirect radiative forcing of climate (IPCC, 2001).

The hygroscopicity of a particle depends on its chemical composition. While the water uptake properties of atmospherically relevant inorganic salts as a function of relative humidity are generally well-known (Tang, 1976; Tang and Munkelwitz, 1994; Weis and Ewing, 1999), the effects of

Published by Copernicus GmbH on behalf of the European Geosciences Union. 
organics on the overall hygroscopic properties are not yet fully understood. Organic compounds are ubiquitous in the atmospheric aerosol. The presence of organic compounds can alter the hygroscopic behavior of inorganic aerosol, sometimes in unanticipated ways (Saxena et al., 1995; Hansson et al., 1998; Li et al., 1998; Ansari and Pandis, 2000; Cruz and Pandis, 2000). A review of recent laboratory and field studies on aerosol hygroscopic properties has been compiled by Jacobson et al. (2000) and Kanakidou et al. (2005).

Secondary organic aerosol (SOA) is formed by the gasparticle partitioning of low-volatility oxidation products of gaseous organic species and can make up a significant fraction of the organic aerosol mass in urban areas (Turpin et al., 1991; Cabada et al., 2002, 2004; Lim and Turpin, 2002). Biogenic terpenes have been identified as precursors of SOA, predominantly in rural or forested areas (Kavouras et al., 1999a, b; Yu et al., 1999; Janson et al., 2001; Pio et al., 2001; Sellegri et al., 2005). As with organic aerosols generally, knowledge of water uptake properties of the SOA is imperative for understanding aerosol evolution and its effect on the regional visibility, cloud formation, and climate.

To date, there have been few laboratory studies on the hygroscopicity of SOA. Those that exist are based on a limited number of hydrocarbon precursors, and some provide data on growth factors $(G F$, defined as the ratio between wet and dry particle diameters) only at a single $R H$. A summary of these studies, as well as two dealing with SOA cloud condensation nuclei $(\mathrm{CCN})$ properties, which are related to hygroscopicity in the sub-saturated regime as measured by the HTDMA, are listed in Table 1. Virkkula et al. (1999) measured hygroscopic growth factors of about 1.1 at $\sim 85 \% R H$ for nucleated SOA from ozonolysis of $\alpha$-pinene, $\beta$-pinene, and limonene. In experiments with seed aerosol, they found that $G F$ was inversely proportional to the organic volume fraction and not the organic layer thickness, indicating that water uptake could be represented by additive uptake of the inorganic and organic fractions. Kleindienst et al. (1999) irradiated toluene, $p$-xylene, and 1,3,5-trimethylbenzene in the presence of $\mathrm{NO}_{\mathrm{x}}$ and $\left(\mathrm{NH}_{4}\right)_{2} \mathrm{SO}_{4}$ seed, collected the particles onto a Teflon filter, and measured the mass changes due to liquid water content of the deposited particles with varying $R H$. They observed water uptake that was slightly less than that of pure $\left(\mathrm{NH}_{4}\right)_{2} \mathrm{SO}_{4}$ but with the same deliquescence point as $\left(\mathrm{NH}_{4}\right)_{2} \mathrm{SO}_{4}$. In a subsequent work, simulated automobile exhaust was similarly photooxidized to nucleate fine particles for analogous bulk liquid water content analysis (Kleindienst et al., 2002). The total amount of organic mass deposited on the filter was not reported; hence the volumetric growth factor could not be inferred, but the general shape of the water uptake curve was similar to those of many pure organic compounds, in that no deliquescence behavior was detected.

Cocker et al. (2001a) found that SOA formed by ozonolysis of $\alpha$-pinene reduces the $G F$ of the $\left(\mathrm{NH}_{4}\right)_{2} \mathrm{SO}_{4}$ seed. In subsequent work, $G F$ of pure nucleated SOA from photooxidation of $m$-xylene, photooxidation of 1,3,5trimethylbenzene, and ozonolysis of $\alpha$-pinene was observed to increase with time in the first seven hours of oxidation (Cocker et al., 2001c). Saathoff et al. (2003) performed $\alpha$ pinene ozonolysis experiments with and without seed (diesel soot, "Palas" soot, and $\left.\left(\mathrm{NH}_{4}\right)_{2} \mathrm{SO}_{4}\right)$ and also found that the aerosol $G F$ increased with time before leveling off in all cases. The final growth factors for $200-\mathrm{nm}$ particles were 1.106 at $85 \% R H$ for the nucleated SOA, $\sim 1.55$ at $90.3 \% R H$ for the SOA deposited on $\left(\mathrm{NH}_{4}\right)_{2} \mathrm{SO}_{4}$ seed, 1.08 at $90 \% R H$ for SOA on diesel soot seeds (although significant nucleation occurred in both of the previous seeded cases, so the growth factors measured may not be representative due to the difference in condensational dynamics induced by presence of freshly formed particles), and $\sim 0.95$ at $90.1 \% R H$ for SOA on "Palas" soot seed. In both experiments involving soot, the condensed organics increased the particle size after humidification compared to an otherwise collapsing soot seed, which is caused by structural rearrangement and compaction of the fractal agglomerates. No deliquescence or efflorescence behavior was observed during $R H$ variation for the nucleated aerosol, but $\mathrm{SOA}$ on $\left(\mathrm{NH}_{4}\right)_{2} \mathrm{SO}_{4}$ deliquesced at $80 \%$ $R H$, similar to pure seed. Baltensperger et al. (2005) reported that the water uptake of nucleated SOA from photooxidation of 1,3,5-trimethylbenzene and $\alpha$-pinene also increased with time but eventually leveled off. The SOA was found to have a smooth water uptake curve with no deliquescence behavior.

Related to the SOA uptake of water in the sub-saturated regime is the ability for the SOA to act as CCN. VanReken et al. (2005) measured the $\mathrm{CCN}$ activation at four supersaturations of SOA formed from ozonolysis of four monoterpenes and a terpenoid alcohol. They found that $\alpha$-pinene SOA is the least $\mathrm{CCN}$ active, and limonene SOA is the most CCN active (across all four supersaturations studied), and that each type of SOA becomes less CCN active with time. Huff Hartz et al. (2005) generated SOA by ozonolysis of four monoterpenes and three sesquiterpenes and found that the monoterpene SOA activates like highly water-soluble organics, while sesquiterpene SOA is less CCN active.

To summarize, these laboratory studies indicate that SOA is slightly hygroscopic; with the exception of the recent work by Baltensperger et al. (2005) and a single $\alpha$-pinene ozonolysis experiment by Saathoff et al. (2003), the quantitative change in SOA water uptake with $R H$ has in general not been measured fully. SOA coatings on inorganic aerosol are found to allow water uptake at lower $R H$ s than the pure inorganic portion alone, which suggests that SOA can play an important role in extending the range of $R H \mathrm{~s}$ over which particlebound water influences aerosol properties, such as density, light scattering, or refractive index. In fact, field measurements have shown that there is a substantial decrease in the $R H$ dependence of light scattering with increasing organic mass fraction (Quinn et al., 2005).

The range of growth factors measured in the previous works is typically consistent with those of the "less 
Table 1. Previous studies involving hygroscopicity or CCN activity of secondary organic aerosols.

\begin{tabular}{|c|c|c|c|c|c|}
\hline Work & Precursor & $\begin{array}{c}\text { Oxidant, } \\
\text { etc. }\end{array}$ & Seed & Technique & Summary of Results \\
\hline $\begin{array}{l}\text { Virkkula } \\
\text { et al. (1999) }\end{array}$ & $\begin{array}{l}\alpha \text {-pinene, } \\
\beta \text {-pinene, } \\
\text { limonene }\end{array}$ & $\mathrm{O}_{3}$ & $\begin{array}{l}\left(\mathrm{NH}_{4}\right)_{2} \mathrm{SO}_{4} \\
\& \\
\text { nucleation }\end{array}$ & TDMA & $\begin{array}{l}\text { Nucleated SOA GF }=1.10 \text { at } \sim 85 \% \mathrm{RH} \text {. } \\
\text { For seed experiments, GF was inversely } \\
\text { proportional to organic volume fraction, } \\
\text { not organic layer thickness. Organic \& } \\
\text { inorganic took up water independently. }\end{array}$ \\
\hline $\begin{array}{l}\text { Kleindienst } \\
\text { et al. (1999) }\end{array}$ & $\begin{array}{l}\text { toluene, } \\
\text { p-xylene, } \\
1,3,5-\mathrm{TMB}\end{array}$ & $\begin{array}{c}\mathrm{NO}_{\mathrm{x}}+ \\
\mathrm{OH}+\mathrm{h} v\end{array}$ & $\left(\mathrm{NH}_{4}\right)_{2} \mathrm{SO}_{4}$ & $\begin{array}{l}\text { LWC } \\
\text { analyzer on } \\
\text { bulk filter }\end{array}$ & $\begin{array}{l}\text { Water uptake at } 5-95 \% \text { slightly lower } \\
\text { than pure }\left(\mathrm{NH}_{4}\right)_{2} \mathrm{SO}_{4} \text {; no significant } \\
\text { contributions from organics. DRH same } \\
\text { as }\left(\mathrm{NH}_{4}\right)_{2} \mathrm{SO}_{4} \text {. Total organic mass } \\
\text { deposited on filter not reported. }\end{array}$ \\
\hline $\begin{array}{l}\text { Cocker et al. } \\
(2001 \mathrm{a})\end{array}$ & $\alpha$-pinene & $\mathrm{O}_{3}$ & $\begin{array}{l}\left(\mathrm{NH}_{4}\right)_{2} \mathrm{SO}_{4} \\
\& \\
\text { nucleation }\end{array}$ & TDMA & $\begin{array}{l}\left(\mathrm{NH}_{4}\right)_{2} \mathrm{SO}_{4} \text { particle GF is reduced by } \\
\text { organics; GF decreases with increasing } \\
\text { organic fraction }\end{array}$ \\
\hline $\begin{array}{l}\text { Cocker et al. } \\
(2001 \mathrm{c})\end{array}$ & $\begin{array}{l}\text { m-xylene, } \\
1,3,5-\mathrm{TMB}\end{array}$ & $\begin{array}{c}\mathrm{NO}_{\mathrm{x}}+ \\
\mathrm{OH}+\mathrm{h} v\end{array}$ & nucleation & TDMA & $\begin{array}{l}\text { GF of SOA increased with time in the } \\
\text { first } 7 \text { hours of oxidation and leveled off } \\
\text { after. }\end{array}$ \\
\hline $\begin{array}{l}\text { Kleindienst } \\
\text { et al. (2002) }\end{array}$ & $\begin{array}{l}\text { simulated } \\
\text { automobile } \\
\text { exhaust }\end{array}$ & $\begin{array}{c}\mathrm{NO}_{\mathrm{x}}+ \\
\mathrm{OH}+\mathrm{hv}\end{array}$ & nucleation & $\begin{array}{l}\text { LWC } \\
\text { analyzer on } \\
\text { bulk filter }\end{array}$ & $\begin{array}{l}\text { Smooth water uptake, no deliquescence. } \\
\text { Total amount of organic mass deposited } \\
\text { on the filter not reported. (Not } \\
\text { quantitative) }\end{array}$ \\
\hline $\begin{array}{l}\text { Saathoff et al. } \\
\text { (2003) }\end{array}$ & $\alpha$-pinene & $\mathrm{O}_{3}$ & $\begin{array}{l}\text { nucleation, } \\
\left(\mathrm{NH}_{4}\right)_{2} \mathrm{SO}_{4}, \\
\text { diesel soot, } \\
\text { "Palas" soot, }\end{array}$ & TDMA & $\begin{array}{l}\text { GF increased with time for the first } 2 \\
\text { hours before leveling off. At } 200 \mathrm{~nm} \text {, GF } \\
=1.106 \text { at } 85 \% \text { RH for nucleated } \mathrm{SOA} \text {, } \\
\sim 1.55 \text { for } \mathrm{SOA} \text { with }\left(\mathrm{NH}_{4}\right)_{2} \mathrm{SO}_{4} \text { seed, } \\
1.08 \text { for } \mathrm{SOA} \text { with Diesel soot seed, and } \\
\sim 0.95 \text { for } \mathrm{SOA} \text { on "Palas" soot seed (last } \\
\text { three at } 90 \% \mathrm{RH}) . \text { No deliquescence for } \\
\text { nucleated aerosol. SOA on }\left(\mathrm{NH}_{4}\right)_{2} \mathrm{SO}_{4} \\
\text { deliquesced at } 80 \% \mathrm{RH} \text {. }\end{array}$ \\
\hline $\begin{array}{l}\text { Baltensperger } \\
\text { et al. }(2005)\end{array}$ & 1,3,5-TMB & $\begin{array}{c}\mathrm{NO}_{\mathrm{x}}+ \\
\mathrm{OH}+\mathrm{h} v \\
\end{array}$ & nucleation & TDMA & $\begin{array}{l}\text { GF increased with time but leveled off } \\
\text { after } 7 \mathrm{hr} \text {. Smooth water uptake curve. }\end{array}$ \\
\hline $\begin{array}{l}\text { VanReken } \\
\text { et al. (2005) }\end{array}$ & $\begin{array}{l}\alpha \text {-pinene, } \\
\beta \text {-pinene, } \\
\Delta^{3} \text {-carene, } \\
\text { limonene, } \\
\text { terpinene-4-ol }\end{array}$ & $\mathrm{O}_{3}$ & nucleation & $\begin{array}{l}\mathrm{CCN} \\
\text { counter }\end{array}$ & $\begin{array}{l}\alpha \text {-pinene SOA is least CCN active, and } \\
\text { limonene SOA is most active (across four } \\
\text { supersaturations studied). SOA becomes } \\
\text { less CCN-active with time. }\end{array}$ \\
\hline $\begin{array}{l}\text { Huff Hartz } \\
\text { et al. }(2005)\end{array}$ & $\begin{array}{c}\alpha \text {-pinene, } \\
\beta \text {-pinene, } \\
\Delta^{3} \text {-carene, } \\
\text { limonene, } \\
\beta \text {-caryophyllene, } \\
\alpha \text {-humulene, } \\
\alpha \text {-cedrene }\end{array}$ & $\mathrm{O}_{3}$ & $\begin{array}{l}\text { Nucleation } \\
\text { \& "self- } \\
\text { seeding" }\end{array}$ & $\begin{array}{l}\mathrm{CCN} \\
\text { counter }\end{array}$ & $\begin{array}{l}\text { Monoterpene SOA is CCN active and } \\
\text { activates like highly water-soluble } \\
\text { organics (cut } \mathrm{D}_{\mathrm{p}} \sim 48 \mathrm{~nm} \text { at } \mathrm{S}=1 \% \text { ). } \\
\text { Sesquiterpene } \mathrm{SOA} \text { is less active }(\sim 120 \\
\mathrm{nm} \text { at } \mathrm{S}=1 \% \text { ). }\end{array}$ \\
\hline
\end{tabular}

hygroscopic" mode found in ambient measurements, in which the observed water uptake and the relative number concentrations of particles in the "more" and "less" hygroscopic modes were found to depend on the time of day and type of air mass (Svenningsson et al., 1992; Covert and Heintzenberg, 1993; Zhang et al., 1993; Swietlicki et al., 1999; Cocker et al., 2001d; Busch et al., 2002; Massling et al., 2003; Ferron et al., 2005). This suggests that the ob- served low-hygroscopicity fraction in ambient aerosol can be attributed to the presence of secondary organic species, in addition to other types of organics or primary soot, which may also be a significant contributor in urban areas. Changes in traffic patterns, such as rush hour traffic, and the distribution and strength of other aerosol precursors, such as terpene-emitting plants, relative to diurnal transport patterns can result in secondary organic aerosol (SOA) contributing 
to ambient aerosol mass to varying degrees, which may explain the observed time dependence in growth factors and hygroscopic mode concentrations.

We report here a comprehensive study performed at the Caltech indoor chamber facility to investigate the hygroscopic behavior of SOA formed by ozonolysis of cycloalkenes and photooxidation of terpenes. Cycloalkenes are a class of compounds that can serve as a model for many atmospheric hydrocarbons with similar molecular skeletons, particularly the anthropogenic pollutants in urban and industrial areas. Terpenes are biogenic hydrocarbons that share a building block of isoprene $\left(\mathrm{C}_{5} \mathrm{H}_{8}\right)$. They are emitted by conifers and broad-leaved trees, and along with isoprene, are among the most abundant reactive organic gases globally (Guenther et al., 1995; Andreae and Crutzen, 1997; Simpson et al., 1999). Terpenes have been observed to be very reactive even at ambient concentrations of oxidants (Holzinger et al., 2005) and to form aerosol with high mass yields (Griffin et al., 1999). The goal of this study is to measure the hygroscopic growth factors of the SOA formed by the oxidation of these parent species, both in pure form (nucleation experiments) and mixed organic-inorganic form (seeded experiments). The relationship between the SOA hygroscopicity and properties of the precursor is explored.

\section{Experimental methods}

\subsection{SOA generation in the smog chamber}

The specifications of the Caltech Indoor Chamber Facility have been described in detail elsewhere (Cocker et al., 2001b; Keywood et al., 2004) and so will only be briefly summarized here. The facility consists of two $28-\mathrm{m}^{3}$ suspended flexible Teflon chambers, which are continuously flushed with clean, particle-free air for at least $36 \mathrm{~h}$ before an experiment. The chambers are preconditioned with the appropriate $R H$, either by passing the flushing air through a silica gel cartridge to achieve air with $<10 \% R H$ for dry experiments, or by passing the flushing air through a sintered stainless steel bubbler placed in a bottle of Milli-Q deionized water (Millipore Corp., Billerica, Massachusetts) to obtain about $50 \% R H$ in humid experiments.

\subsubsection{Cycloalkene ozonolysis}

The experimental procedure for the cycloalkene ozonolysis experiments is described in detail in Keywood et al. (2004). To summarize, about 20000 particles $/ \mathrm{cm}^{3}$ of ammonium sulfate seed aerosol is atomized using a stainless steel constantflow atomizer from a $0.03 \mathrm{M}\left(\mathrm{NH}_{4}\right)_{2} \mathrm{SO}_{4}$ solution, dried using a diffusion dryer, and introduced into a clean chamber. The initial dry seed size distribution has a mode diameter of approximately $70-80 \mathrm{~nm}$ and geometric standard deviation $\left(\sigma_{g}\right)$ of $\sim 1.75$. Approximately $200 \mathrm{ppb}$ of the cycloalkene parent compound of interest is then volatilized in a glass bulb and injected in a stream of air along with cyclohexane, which serves as a hydroxyl radical scavenger. The amount of cyclohexane injected is such that the reaction rate of $\mathrm{OH}$ radicals with cyclohexane is 100 times faster than that with the cycloalkene being studied. When both concentrations have reached steady state, 400-600 ppb of ozone are injected using a UV lamp ozone generator (EnMet Corp, Michigan) to start the oxidation reaction in an excess-ozone regime. The experiments are performed in the dark at $<10 \% R H$ and $20 \pm 1^{\circ} \mathrm{C}$. For nucleation experiments, no seed aerosol is used, and pure organic particles are formed when oxidation products nucleate.

Four simple and five substituted cycloalkenes are studied in this work: cyclopentene, cyclohexene, cycloheptene, cyclooctene, 1-methyl cyclopentene, 1-methyl cyclohexene, 1methyl cycloheptene, 3-methyl cyclohexene, and methylene cyclohexane. The molecular structures and relevant properties of these compounds as well as the terpene precursors (see below) are shown in Table 2.

Hypothetically, the reaction mechanism of the cycloalkene ozonolysis could be dependent on humidity. For example, higher $R H$ could increase the reaction rate of stabilized Criegee intermediates with water molecules, potentially changing the distribution of semivolatile species. However, it has been suggested that the effect of water on the stabilized Criegee intermediate of smaller cycloalkenes (carbon number of 8 or less) would be minor, since the dominant reaction pathway is through that of the excited Criegee intermediate that readily break down into other products (Chuong et al., 2004). In the end, it is unlikely that such minor effects on chemical composition would be captured by the hygroscopicity measurement. Because of this and the fact that the cycloalkene family was meant to be a set of "model compounds" rather than representative of atmospherically relevant species like the biogenics, the dry condition was deemed sufficient for the hygroscopicity and yield measurements.

\subsubsection{Terpene photooxidation}

Photooxidation experiments of eight monoterpenes, four sesquiterpenes, and three oxygenated terpenes are performed individually in a humid chamber $(R H \sim 50 \%)$. Deliquesced $\left(\mathrm{NH}_{4}\right)_{2} \mathrm{SO}_{4}$ seed is generated by atomization as above but without the diffusion dryer, resulting in an initial size distribution in the chamber with a mode diameter of approximately $80-100 \mathrm{~nm}$ and geometric standard deviation of $\sim 1.80$. $\quad\left(\mathrm{NH}_{4}\right)_{2} \mathrm{SO}_{4}$ seed is used for experiments with monoterpenes and oxygenated terpenes, which include $\alpha$-pinene, $\beta$-pinene, $\Delta^{3}$-carene, limonene, $\alpha$ terpinene, $\gamma$-terpinene, terpinolene, myrcene, methyl chavicol, verbenone, and linalool. The initial concentrations of these compounds are approximately $120 \mathrm{ppb}$.

Because the higher-molecular-weight sesquiterpenes react extremely quickly with the $\mathrm{OH}$ radical to form low-volatility condensable products that readily form fresh particles even 
Table 2. Hydrocarbon precursors studied.

\begin{tabular}{|c|c|c|c|c|c|}
\hline $\begin{array}{c}\text { Parent } \\
\text { Hydrocarbon }\end{array}$ & $\begin{array}{l}\text { Molecular } \\
\text { structure }\end{array}$ & $\begin{array}{l}\text { Molecular } \\
\text { formula }\end{array}$ & $\begin{array}{l}\text { Molecular } \\
\text { Weight } \\
\text { (g/mol) }\end{array}$ & $\begin{array}{l}\text { Reported } \\
\text { Purity }\end{array}$ & Supplier \\
\hline \multicolumn{6}{|c|}{ Cycloalkenes } \\
\hline cyclopentene & & $\mathrm{C}_{5} \mathrm{H}_{8}$ & 68.12 & $96 \%$ & Aldrich \\
\hline cyclohexene & & $\mathrm{C}_{6} \mathrm{H}_{10}$ & 82.15 & $\geq 99 \%$ & Aldrich \\
\hline cycloheptene & & $\mathrm{C}_{7} \mathrm{H}_{12}$ & 96.17 & $97 \%$ & Aldrich \\
\hline cyclooctene & & $\mathrm{C}_{8} \mathrm{H}_{14}$ & 110.20 & $95 \%$ & Aldrich \\
\hline \multicolumn{6}{|c|}{ Substituted cycloalkenes \& related compounds } \\
\hline $\begin{array}{l}\text { 1-methyl } \\
\text { cyclopentene }\end{array}$ & & $\mathrm{C}_{6} \mathrm{H}_{10}$ & 82.15 & $98 \%$ & Aldrich \\
\hline $\begin{array}{l}\text { 1-methyl } \\
\text { cyclohexene }\end{array}$ & & $\mathrm{C}_{7} \mathrm{H}_{12}$ & 96.17 & $97 \%$ & Aldrich \\
\hline $\begin{array}{l}\text { 1-methyl } \\
\text { cycloheptene }\end{array}$ & & $\mathrm{C}_{8} \mathrm{H}_{14}$ & 110.20 & $98 \%$ & Chemsampco \\
\hline $\begin{array}{l}\text { 3-methyl } \\
\text { cyclohexene }\end{array}$ & & $\mathrm{C}_{7} \mathrm{H}_{12}$ & 96.17 & $95 \%$ & TCI America \\
\hline $\begin{array}{l}\text { methylene } \\
\text { cyclohexane }\end{array}$ & & $\mathrm{C}_{7} \mathrm{H}_{12}$ & 96.17 & $98 \%$ & Aldrich \\
\hline \multicolumn{6}{|c|}{ Sesquiterpenes } \\
\hline$\alpha$-humulene & & $\mathrm{C}_{15} \mathrm{H}_{24}$ & 204.35 & $\begin{array}{c}\text { not } \\
\text { reported }\end{array}$ & Sigma \\
\hline$\beta$-caryophyllene & & $\mathrm{C}_{15} \mathrm{H}_{24}$ & 204.35 & $\begin{array}{c}\text { not } \\
\text { reported }\end{array}$ & Aldrich \\
\hline aromadendrene & & $\mathrm{C}_{15} \mathrm{H}_{24}$ & 204.35 & $\geq 97 \%$ & Fluka \\
\hline longifolene & & $\mathrm{C}_{15} \mathrm{H}_{24}$ & 204.35 & $\geq 99 \%$ & Fluka \\
\hline
\end{tabular}

in the presence of seed, photooxidation experiments of $\alpha$-humulene, $\beta$-caryophyllene, longifolene, and aromadendrene are performed without preexisting seed. In this way, a cleaner system with only pure nucleated SOA particles is achieved. An initial mixing ratio of $\sim 40 \mathrm{ppb}$ of these sesquiterpenes is used in each experiment.

All terpene injections are carried out with clean humid air $(R H \sim 50 \%)$ to prevent the particles in the chamber from efflorescing. Nitrous acid (HONO) is used as the $\mathrm{OH}$ radical source. HONO is prepared by drop-wise addition of $2 \mathrm{~mL}$ of $1 \% \mathrm{NaNO}_{2}$ into $15 \mathrm{~mL}$ of $10 \% \mathrm{H}_{2} \mathrm{SO}_{4}$, which also produces $\mathrm{NO}_{\mathrm{x}}$ as a byproduct. After the terpene injection, HONO is introduced into the chamber by passing air over the mixture until the steady-state volumetric mixing ratio of $\mathrm{NO}_{\mathrm{x}}$ is equal to that of the parent terpene. Ultraviolet lights are switched on to photolyze HONO into $\mathrm{OH}$ and NO, which marks the beginning of the experiment. In general, approximately 1$2{ }^{\circ} \mathrm{C}$ of temperature increase is measured during the course of an experiment (due to heating from the lights). The $R H$ never drops below $40 \%$, the efflorescence $\mathrm{RH}$ of $\left(\mathrm{NH}_{4}\right)_{2} \mathrm{SO}_{4}$; thus, the seed aerosol always exists in the deliquesced state. 
Table 2. Continued.

\begin{tabular}{|c|c|c|c|c|c|}
\hline $\begin{array}{c}\text { Parent } \\
\text { Hydrocarbon }\end{array}$ & $\begin{array}{l}\text { Molecular } \\
\text { structure }\end{array}$ & $\begin{array}{l}\text { Molecular } \\
\text { formula }\end{array}$ & $\begin{array}{l}\text { Molecular } \\
\text { Weight } \\
\text { (g/mol) }\end{array}$ & $\begin{array}{c}\text { Reported } \\
\text { Purity }\end{array}$ & Supplier \\
\hline \multicolumn{6}{|c|}{ Monoterpenes } \\
\hline$\alpha$-pinene & & $\mathrm{C}_{10} \mathrm{H}_{16}$ & 136.24 & $\geq 99 \%$ & Aldrich \\
\hline$\beta$-pinene & & $\mathrm{C}_{10} \mathrm{H}_{16}$ & 136.24 & $\geq 99 \%$ & Fluka \\
\hline$\Delta^{3}$-carene & & $\mathrm{C}_{10} \mathrm{H}_{16}$ & 136.24 & $99 \%$ & Aldrich \\
\hline limonene & & $\mathrm{C}_{10} \mathrm{H}_{16}$ & 136.24 & $97 \%$ & Aldrich \\
\hline$\alpha$-terpinene & & $\mathrm{C}_{10} \mathrm{H}_{16}$ & 136.24 & $\geq 97 \%$ & Fluka \\
\hline$\gamma$-terpinene & & $\mathrm{C}_{10} \mathrm{H}_{16}$ & 136.24 & $\geq 98.5 \%$ & Fluka \\
\hline terpinolene & & $\mathrm{C}_{10} \mathrm{H}_{16}$ & 136.24 & $\geq 97 \%$ & Fluka \\
\hline myrcene & & $\mathrm{C}_{10} \mathrm{H}_{16}$ & 136.24 & $90 \%$ & Fluka \\
\hline \multicolumn{6}{|c|}{ Oxygenated terpenes } \\
\hline $\begin{array}{l}\text { methyl chavicol } \\
\text { (4-allylanisole) }\end{array}$ & & $\mathrm{C}_{10} \mathrm{H}_{12} \mathrm{O}$ & 148.20 & $\geq 98.5$ & Fluka \\
\hline verbenone & & $\mathrm{C}_{10} \mathrm{H}_{14} \mathrm{O}$ & 150.22 & $99 \%$ & Fluka \\
\hline linalool & & $\mathrm{C}_{10} \mathrm{H}_{18} \mathrm{O}$ & 154.25 & $97 \%$ & Fluka \\
\hline
\end{tabular}

\subsection{Analytical instrumentation}

\subsubsection{Chamber instrumentation}

During the experiments, the aerosol size distribution is monitored using a scanning differential mobility analyzer (DMA) (Wang and Flagan, 1990). A condensation particle counter (CPC) 3010 or 3025 (TSI Inc., St. Paul, MN) provided another independent measurement for the particle number concentration. An Aerodyne quadrupole aerosol mass spectrometer (AMS) (Jayne et al., 2000; Allan et al., 2003) is used to measure the size-resolved aerosol chemical composition for most of the experiments. Bahreini et al. (2005) reported detailed findings from the AMS from the cycloalkene experiments, including its use in the estimation of aerosol density. The sampling and analysis are carried out in a similar manner for the biogenic photooxidation experiments.

To measure the gas-phase concentrations of the precursor hydrocarbon, a Hewlett Packard 5890 series II gas chromatograph with flame ionization detector (GC-FID) is used (now Agilent Technologies Inc., Palo Alto, CA). In experiments involving terpenes, a proton transfer reaction mass spectrometer, or PTR-MS, (Ionicon Analytik, Innsbruck, Aus- tria) (Lindinger et al., 1998) is used to monitor the evolution of gas-phase precursors. Details on the PTR-MS calibration techniques for these terpenes can be found in Lee et al. (2006). Ozone, $\mathrm{NO}$, and $\mathrm{NO}_{2}$ concentrations are measured using a Horiba APOA-360 ozone monitor and an APNA-360 $\mathrm{NO}_{\mathrm{x}}$ monitor, respectively (Horiba Instruments Inc., Irvine, CA). The temperature and $R H$ are measured using Vaisala HMP233 hygrometer probes and transmitters (Vaisala Inc., Woburn, MA). The aerosol hygroscopicity is measured using the hygroscopicity tandem differential mobility analyzer (HTDMA), which is described in more detail below.

\subsubsection{Hygroscopicity Tandem differential mobility ana- lyzer (HTDMA)}

The HTDMA (Liu et al., 1978; Rader and McMurry, 1986; McMurry and Stolzenburg, 1989) is a widely-used method of measuring changes of submicron particle size with $R H$. The instrument used here is based on that described previously (Cocker et al., 2001b, d), but with improvements in the aerosol charging, $R H$ measurement, CPC unit, data acquisition boards, and LabVIEW program. A schematic of the 


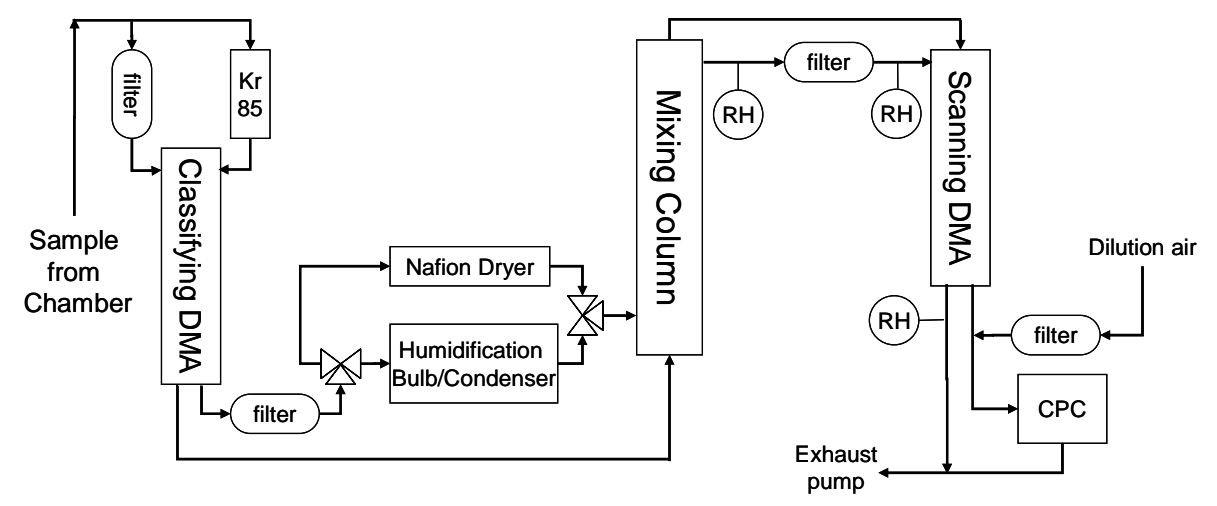

Fig. 1. Schematic of the HTDMA system used.

setup is illustrated in Fig. 1. SOA from the chamber is first passed through a TSI ${ }^{85} \mathrm{Kr}$ charger (Model 3077, TSI Inc., St. Paul, MN) to achieve equilibrium charge distribution and is then classified at constant voltage in the first cylindrical DMA (Model 3071, TSI Inc, St. Paul, MN) to a specified diameter, usually 60,180 , or $300 \mathrm{~nm}$, depending on the size distribution of the aerosol in the chamber.

Changing the $R H$ of the carrier air is achieved by passing the filtered excess flow from the classifying DMA through either a humidification or a drying system. The humidification system consists of a water saturator bath, followed by a temperature-controlled condenser. By adjusting the temperature of the ethylene glycol fluid flowing through the condenser coil from $2^{\circ} \mathrm{C}$ to room temperature $\left(\sim 20^{\circ} \mathrm{C}\right)$ using a refrigerated bath/circulator (RTE Series, Neslab Instruments Inc., Portsmouth, NH), the equilibrium $R H$ of the carrier air can be varied roughly between $25-92 \%$. The drying system consists of a 200-tube Nafion membrane dryer (Model PD200T-12SS, Perma Pure LLC, Toms River, NJ), which uses a stream of dry air at $0.5 \mathrm{~atm}$ pressure as the purge air to carry away moisture across the membrane from the sample air. The system is able to dry humid air from the chamber down to $\sim 8 \% R H$. Both the humidification and the drying system can be completely bypassed, allowing verification of the classified aerosol size (at the chamber $R H$ of either $<10 \%$ or $\sim 50 \%$ ).

Monodisperse aerosol from the classifying DMA is mixed with the $R H$-conditioned air in an insulated, laminar flow mixing column, which has a residence time of approximately $38 \mathrm{~s}$. The particles experience hygroscopic growth (or shrinkage) in this column and enter the second DMA, operating in scanning mode to measure the new aerosol size distribution. The scanning DMA sheath flow is also drawn from the humidification column; in this manner, the gaseous organic oxidation products are preserved, and re-partitioning of these species between the particle and gas phase, which may alter the aerosol water affinity and content, is reduced. Two Vaisala hygrometer probes (Models HMM211 and HMP233, Vaisala Inc., Woburn, MA) are used to measure the tempera- ture and $R H$ immediately before and after the scanning DMA on the sheath and excess flows. Classified particles from the scanning DMA are detected with a TSI Model 3760A CPC with dilution flow from filtered room air. Both DMAs are operated at $2.5 \mathrm{~L} / \mathrm{min}$ sheath and excess flow rates and $0.25 \mathrm{~L} / \mathrm{min}$ aerosol and monodisperse flow rates. The particle size classification by the DMAs has been validated by sampling polystyrene latex (PSL) spheres of known sizes (Duke Scientific Corp., Palo Alto, CA).

Inversion of the scanning DMA data (Collins et al., 2002) yields the size distribution of the grown droplets, which can then be fitted with a lognormal curve to obtain a mode diameter corresponding to the peak of the distribution. The hygroscopic growth factor $(G F)$ at a certain $R H$ is then defined as the ratio of the diameter of the humidified particle, $D_{p \text {,wet }}$, to that of the dry classified particle, $D_{p, \text { dry }}$ :

$G F=\frac{D_{p, \text { wet }}}{D_{p, \text { dry }}}$

During the dry cycloalkene ozonolysis experiments, the mixing column $R H$ is set at a constant elevated value between $85-90 \%$ in order to measure the change in aerosol hygroscopicity as the condensation of low-volatility organic oxidation products progresses. After the chamber aerosol has grown to a maximum volume, the $R H$ in the HTDMA is then varied between $<10 \%$ (no humidification) and $92 \%$ in order to measure the dependence on SOA growth factor on $R H$. Figure 2a shows an image plot of the resulting droplet size distribution and the $R H$ variation scheme. The thick black line marks the monodisperse particle size classified in the first DMA. The results on the growth factors will be discussed in the next section.

For terpene photooxidation experiments, which are performed in a humid chamber, the drying system is used instead to remove the water in the gas stream between the classifying and scanning DMA. After the maximum aerosol volume has been reached in the chamber, the $R H$ is then varied in a similar manner as in the dry experiments (Fig. 2b). Note that the reported growth factors for these humid photooxidation 

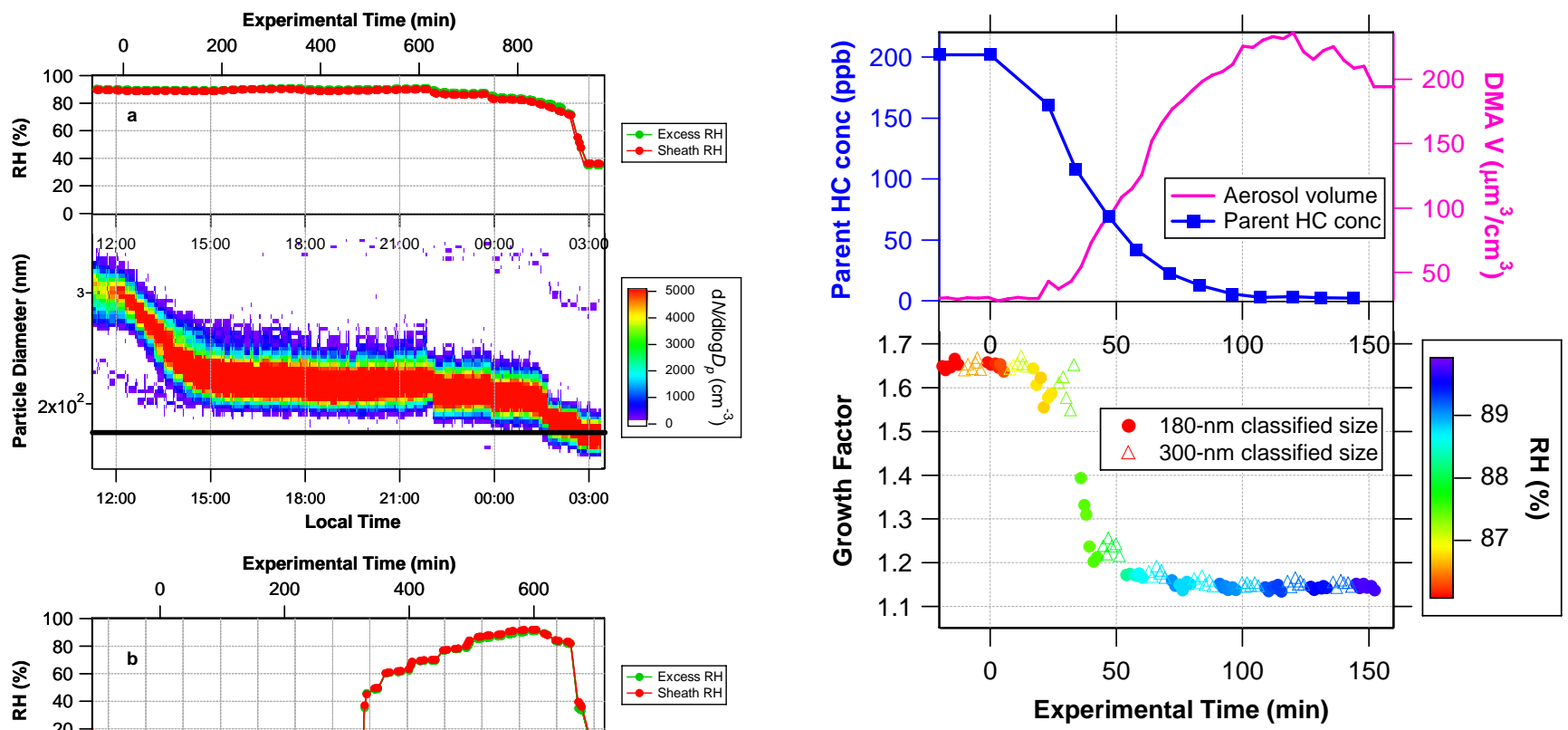

Fig. 3. Aerosol hygroscopic growth factor decreases as the precursor cycloalkene is consumed and the gas-to-particle partitioning of organic products occurs onto $\left(\mathrm{NH}_{4}\right)_{2} \mathrm{SO}_{4}$ seed. The data points shown are from a $202 \mathrm{ppb} 1$-methyl cyclohexene + ozone experiment.

cles after three complete up- and down-scan cycles at each size, with a 70-s delay between the switch and the start of scanning at the new size to prevent contamination. For nu-

Fig. 2. Image plots of raw TDMA data and the variations in $R H$ in a typical operating scheme for (a) cycloalkene ozonolysis experiments (dry) and (b) terpene photooxidation experiments (humid). The data shown here are from ozonolysis of $181 \mathrm{ppb}$ of methylene cyclohexane in the presence of $\left(\mathrm{NH}_{4}\right)_{2} \mathrm{SO}_{4}$ seed and photooxidation of $105 \mathrm{ppb}$ verbenone in the presence of $\left(\mathrm{NH}_{4}\right)_{2} \mathrm{SO}_{4}$ seed, respectively. The thick black line in each image plot denotes the classified particle size of $180 \mathrm{~nm}$.

experiments are obtained by dividing the diameter of the grown droplet at a certain $R H$ by the final dried diameter of the aerosol (rather than the diameter of the classified aerosol, which still contains some water).

The humidity probes are regularly calibrated against a set of saturated salt solutions in the range of $11 \%-93 \% R H$. The HTDMA measurement is validated with ammonium sulfate, the growth factor of which as a function of $R H$ is wellknown. The HTDMA is found to be able to reproduce the hygroscopic growth curve that agrees to within 0.01 in $G F$ compared to theoretically calculated $G F$ of 1.484 at $80 \% R H$ (Nenes et al., 1998), equivalent to an error of about $1.5 \%$ $(\mathrm{n}=18)$. The precision of the measurement, measured from the same $\left(\mathrm{NH}_{4}\right)_{2} \mathrm{SO}_{4}$ experiment, is $1 \%(\mathrm{n}=18)$. To capture the growth factors at different particle sizes, the HTDMA is set to switch between classifying $180-\mathrm{nm}$ and $300-\mathrm{nm}$ particleated SOA, 60-nm particles are selected.

\section{Results and discussion}

\subsection{Cycloalkene ozonolysis}

3.1.1 Seeded experiments: SOA formation on inorganic substrate

At the beginning of a seeded experiment, the aerosol $G F$ at a fixed $R H$ is equal to that of pure $\left(\mathrm{NH}_{4}\right)_{2} \mathrm{SO}_{4}$ but quickly decreases as the less-hygroscopic organic oxidation products partition into the particle phase (Fig. 3). A similar reduction in hygroscopicity of SOA containing seed aerosol has been observed in the oxidation of $\alpha$-pinene, $\beta$-pinene, and limonene (Virkkula et al., 1999; Cocker et al., 2001a). In our experiments, the $G F$ of 180 -nm classified particles decreases at a faster rate than that of $300-\mathrm{nm}$ particles due to preferential condensation of organic material on smaller particles.

During the period of rapid decline in particle hygroscopicity, we also observe bimodal humidified droplet spectra in the HTDMA (Fig. 4), similar to those observed for ambient aerosol (Svenningsson et al., 1992; Covert and Heintzenberg, 1993; Zhang et al., 1993; Swietlicki et al., 1999; Cocker et al., 2001d; Busch et al., 2002; Massling et al., 2003; 
Ferron et al., 2005). For most parent cycloalkenes, the dominance in number concentration shifts from the more hygroscopic mode to the less hygroscopic mode, such that the less hygroscopic mode dominates the droplet distribution in the end (Fig. 4a). However, for a few parent compounds with low SOA yield, e.g. cyclopentene and 1-methyl cyclopentene (Keywood et al., 2004), the more hygroscopic mode can remain dominant even after the maximum organic volume is achieved, resulting in clear bimodal structure during the entire experiment (Fig. 4b).

The bimodal droplet distribution is most likely caused by significant differences in the organic volume fractions in the particles selected by the classifying DMA early in experiment, which could, in turn, be caused by a number of factors. First, classified particles of a certain diameter could have been formed in the chamber from an array of different seed diameters, with initially larger seeds having gained a relatively small amount of organics (becoming the more hygroscopic mode), and initially smaller seeds having gained relatively more organics (becoming the less hygroscopic mode). Such different particle growth trajectories, which also results in the narrowing aerosol size distribution as measured by the DMA, can lead to monodisperse particles having a range of organic fractions. While this phenomenon was probably occurring in the chamber to some degree, it is unlikely that a smooth range of organic fractions could give rise to a distinctly bimodal droplet distribution.

The relatively slow ozone injection, which takes up to $2.5 \mathrm{~h}$ to complete, can also cause the chamber to be slightly inhomogeneous, especially near the injection port where ozone is constantly introduced. Different histories of exposure to ozone and therefore to oxidation products stemming from this lack of complete mixing can also lead to different organic fractions in particles of the same size. Finally, because the DMA selects particles by their electrical mobility, larger, doubly-charged particles with the same electrical mobility as that of the expected singly-charged particles can be transmitted through the classifying DMA. Thus, the droplet distribution detected by the scanning DMA would reflect the hygroscopic growth of both the singly-charged particles of the expected size and a small fraction of multiply-charged larger particles that, as a result of the aforementioned preferential condensation of organic vapors onto smaller particles, have a lower organic fraction. Using the aerosol size distribution in the chamber and approximating the size-dependent equilibrium charge distribution according to Wiedensohler (1988), we can estimate the influence of doubly-charged 289-nm particles transmitted at the same voltage as singlycharged $180-\mathrm{nm}$ particles to be about $10 \%$ of the number of singly-charged particles. While this fraction will increase as the experiment progresses due to larger number of particles at $289 \mathrm{~nm}$, the relative difference between the organic fractions at 180 and $289 \mathrm{~nm}$ also decreases quickly with time, and the organic fractions of both sizes quickly approach unity for most compounds. Thus, the "error" in $G F$ due to doubly-
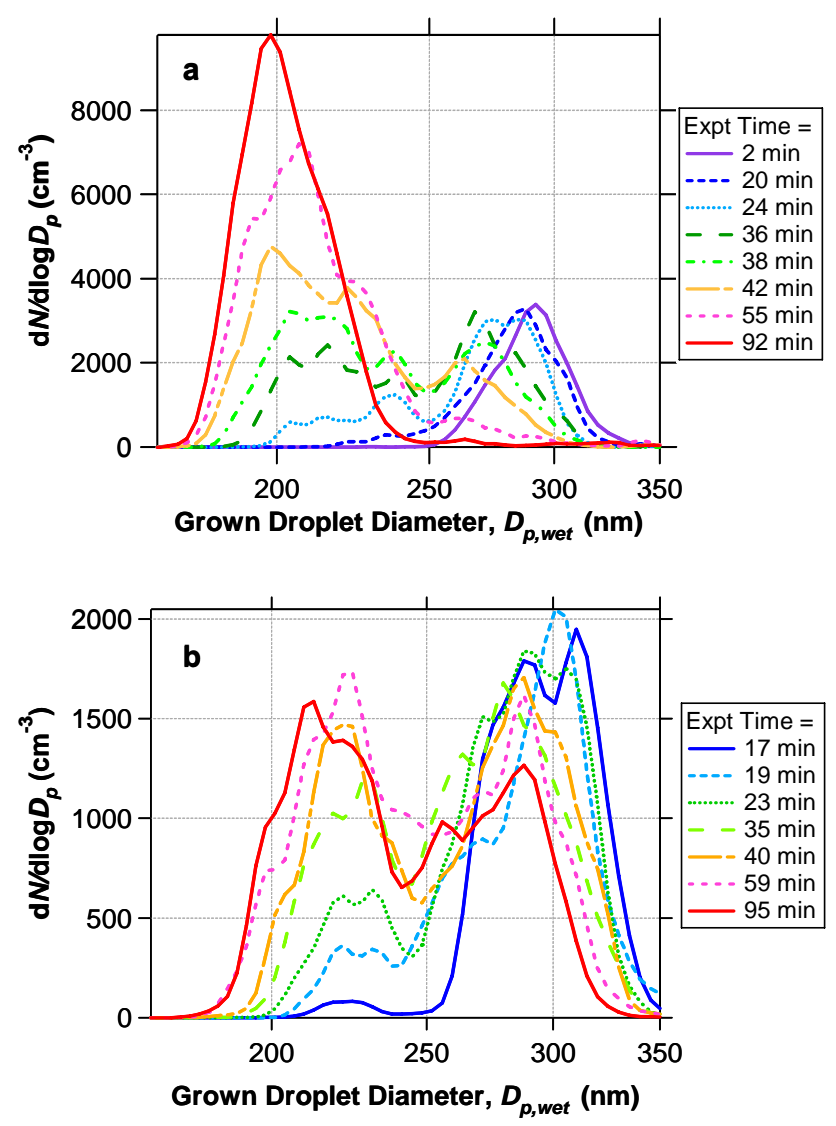

Fig. 4. Bimodal size distribution of grown droplets at classified diameter of $180 \mathrm{~nm}$, observed during early times in experiments. The curve corresponding to the latest time in each case is the final shape of the droplet spectrum. (a) For most compounds, the bimodal shape shifts such that the less hygroscopic mode dominates the droplet spectrum at the end of the experiment. The curves shown are from ozonolysis of $202 \mathrm{ppb}$ of 1-methyl cyclohexene, at an $R H$ of $88 \%$. (b) In experiments with low-aerosol-yield precursors, such as cyclopentene or 1-methyl cyclopentene, both modes remain comparable in size even after the organic volume has leveled off. The curves shown are from ozonolysis of $186 \mathrm{ppb}$ of 1-methyl cyclopentene.

charged particles will be minimal by the time the organic volume levels off and when the $R H$ ramping in the HTDMA starts.

In the seeded, humid terpene experiments (discussed in the Sect. 3.2.2 below), a bimodal distribution of the dried aerosol is not observed at early times as in the case of cycloalkene ozonolysis SOA grown droplets. This observation suggests that the inhomogeneity in the chamber due to slow ozone injection is probably the most likely cause of this phenomenon in the cycloalkene seeded experiments. Regardless of the exact cause of the bimodal structure at early times, the droplet distribution evolves to an essentially unimodal distribution by the end of most experiments. The SOA $G F$ approaches an asymptote as the aerosol volume reaches the maximum, 


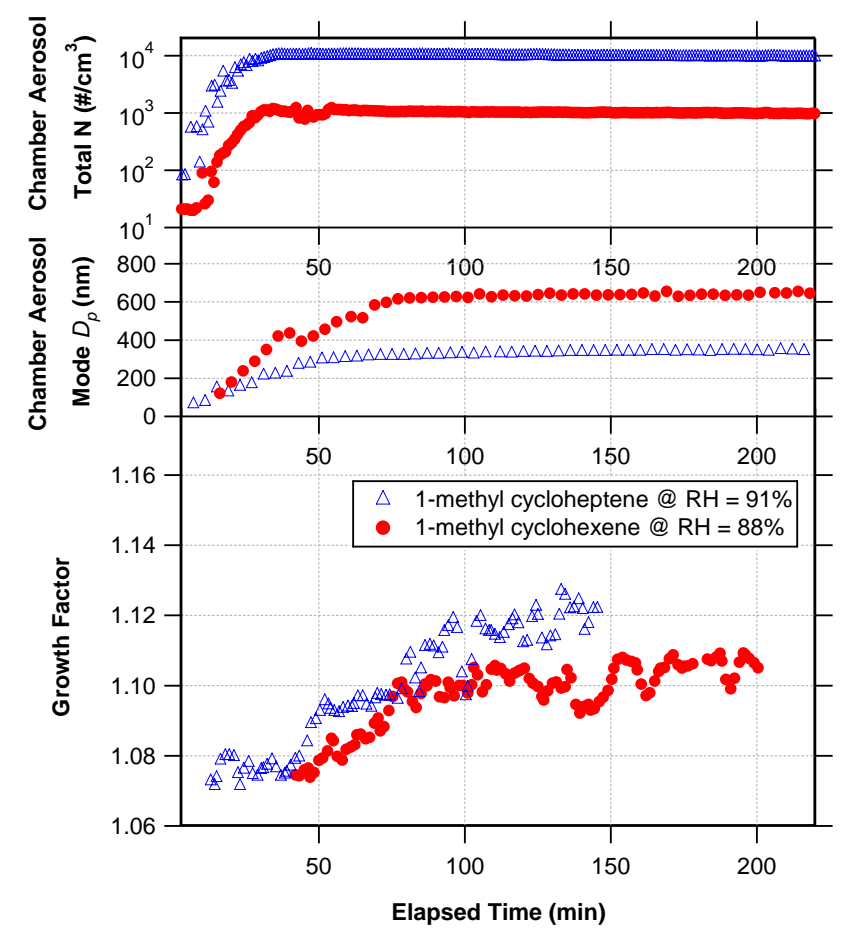

Fig. 5. Time series of the particle number concentration (as measured by CPC) and mode diameter of the chamber aerosol and the TDMA growth factor in two cycloalkene ozonolysis nucleation experiments. The growth factor of the nucleated SOA increases with time early in the experiment, consistent with further oxidation of organic products into more polar and more hydrophilic species. The $G F$ data shown are from 180-nm classified diameter.

with almost no difference between the two classified sizes (Fig. 3).

\subsubsection{Nucleation experiments: pure SOA}

In order to measure the growth factor as a function of $R H$ for pure SOA products, cycloalkene ozonolysis experiments were also performed in the absence of seed particles. By sampling nucleated SOA from these systems, we can directly obtain SOA $G F$ with minimal uncertainties. The ozonolysis products of all of the cycloalkene species studied except for 1-methyl cyclopentene and methylene cyclohexane nucleate and grow large enough particles to be sampled by the HTDMA. These two excepted compounds generally form products with low molecular weights and/or high volatilities, which do not trigger formation of significant numbers of particles. The ozonolysis of methylene cyclohexane forms no particles, and that of 1-methyl cyclopentene forms less than 80 particles $/ \mathrm{cm}^{3}$, which are too few to yield quantitative results in the HTDMA.

The water uptake of pure nucleated SOA formed by cycloalkene ozonolysis increases slightly with time early in experiment as shown in Fig. 5. This behavior is similar

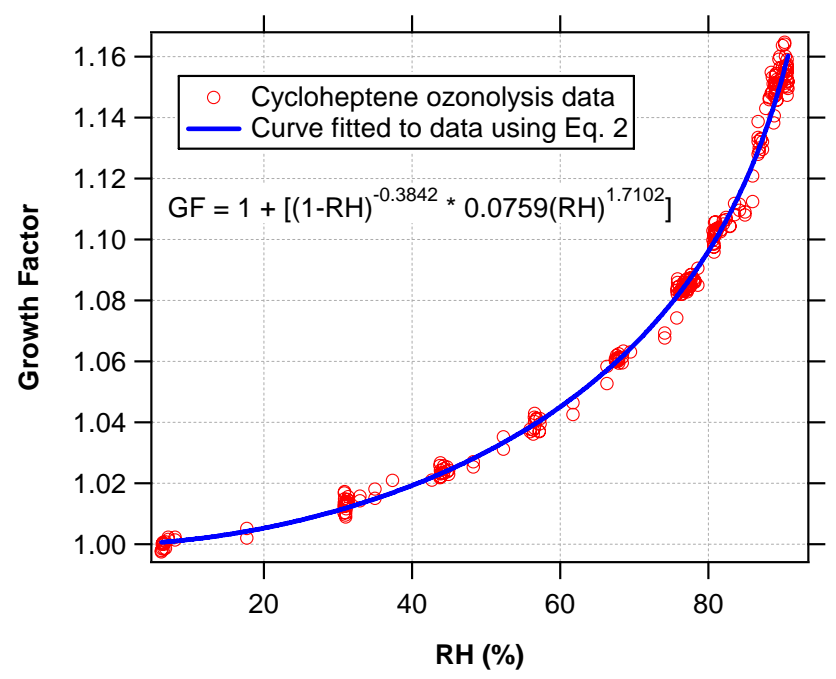

Fig. 6. Hygroscopic growth factor as a function of $R H$ for nucleated SOA formed by ozonolysis of $170 \mathrm{ppb}$ of cycloheptene. The growth curve is smooth, and no deliquescence or efflorescence is observed. The fitted curve is the empirical three-parameter fit of the form of Eq. (2).

to observations made in other works for $\alpha$-pinene ozonolysis (Cocker et al., 2001a; Saathoff et al., 2003), and $m$ xylene, 1,3,5-trimethylbenzene, and $\alpha$-pinene photooxidation (Cocker et al., 2001c; Baltensperger et al., 2005). The likely reason for this trend is the formation of more highly oxidized species in the aerosol, which tend to be more hygroscopic.

When the maximum organic aerosol volume is achieved, the $R H$ in the HTDMA humidification chamber is ramped up and down to study the variation in $G F$ with $R H$. All of the SOA formed in the cycloalkene ozonolysis exhibit slight hygroscopicity with no observable deliquescence behavior. Figure 6 shows an example of the hygroscopic growth curve of the nucleated SOA from cycloheptene ozonolysis. In order to fit a curve through the experimental data, we use an equation of the following empirical functional form:

$G F=1+\left[\left(1-\frac{R H}{100}\right)^{-A} \times B\left(\frac{R H}{100}\right)^{C}\right]$

where $R H$ is the relative humidity expressed between 0 and 100 , and $A, B$, and $C$ are positive empirical parameters. The first part of the product term is the functional form previously used to model the "more hygroscopic" portion of aerosol over the Northeastern Atlantic during ACE-2 (Swietlicki et al., 2000). The second part of the product term is the general power-law form commonly used to represent dicarboxylic acid hygroscopic behavior in a limited range of $R H$ (Wise et al., 2003). While each of these functional forms does not satisfactorily fit our experimental data in their entire range, the product of the two proves to be quite robust in representing our data. A fit of the cycloheptene ozonolysis SOA data is 


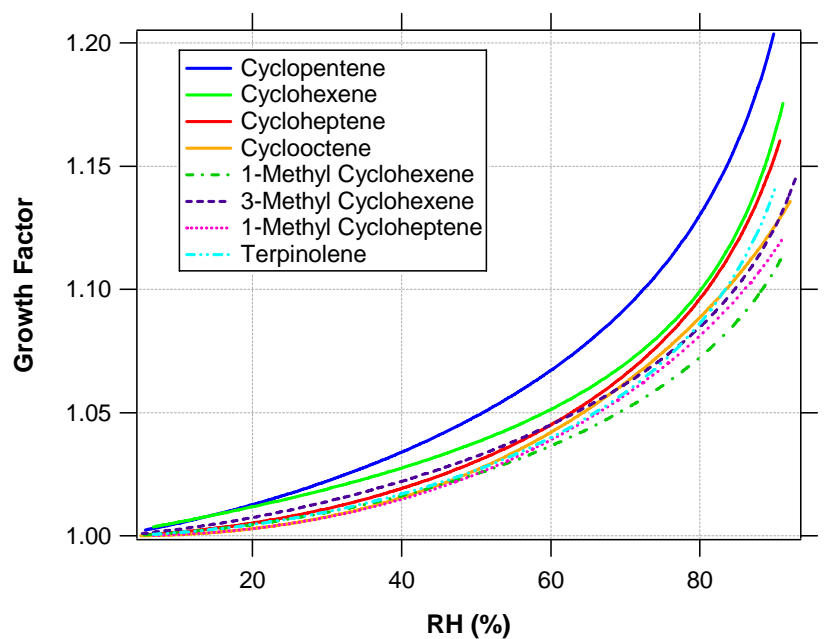

Fig. 7. Fitted curves of hygroscopic growth factors as a function of $R H$ for nucleated SOA formed by ozonolysis of various cycloalkenes. Fitting parameters used to generate the curves are given in Table 3. In general, pure cycloalkene ozonolysis SOA is slightly hygroscopic, with $G F$ between $1.09-1.16$ at $85 \% R H$.

also shown in Fig. 6. Table 3 shows the fit parameters of SOA hygroscopicity data obtained for all cycloalkene compounds studied. From these parameters and Eq. (2), the growth factor of each type of SOA at a given $R H$ can be computed. These interpolated $G F$ values at $50 \%$ and $85 \% R H$ are also shown in Table 3. In general, pure cycloalkene ozonolysis SOA is slightly hygroscopic, and the water uptake behavior varies somewhat within the family, with $G F$ values between $1.09-1.16$ at $85 \% R H$. Figure 7 shows the fitted hygroscopic growth curve for all the nucleated cycloalkenes. Comparison of $G F$ from different systems will be discussed in Sect. 3.4.

\subsection{Terpene photooxidation}

\subsubsection{Sesquiterpenes - nucleated SOA}

In the beginning of humid photooxidation experiments involving terpenes, the chamber aerosol is dried before entering the second DMA of the HTDMA to $~ 8 \%$. Assuming that all the SOA-bound water is removed at this low $R H$, and that the change in particle volume due to mixing of water and SOA products is negligible, we can calculate the percent water content (by volume), $\% W C$, of the chamber aerosol by:

$\% W C=\left[1-\left(\frac{D_{p, \text { dry }}}{D_{p, \text { classified }}}\right)^{3}\right] * 100$

where $D_{p, \text { dry }}$ is the particle diameter measured at $8 \% R H$,

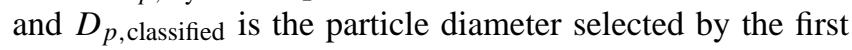
DMA. Figure 8 shows that the percent water content of the nucleated sesquiterpene SOA in the chamber decreases as a function of time early in the experiment and levels off within

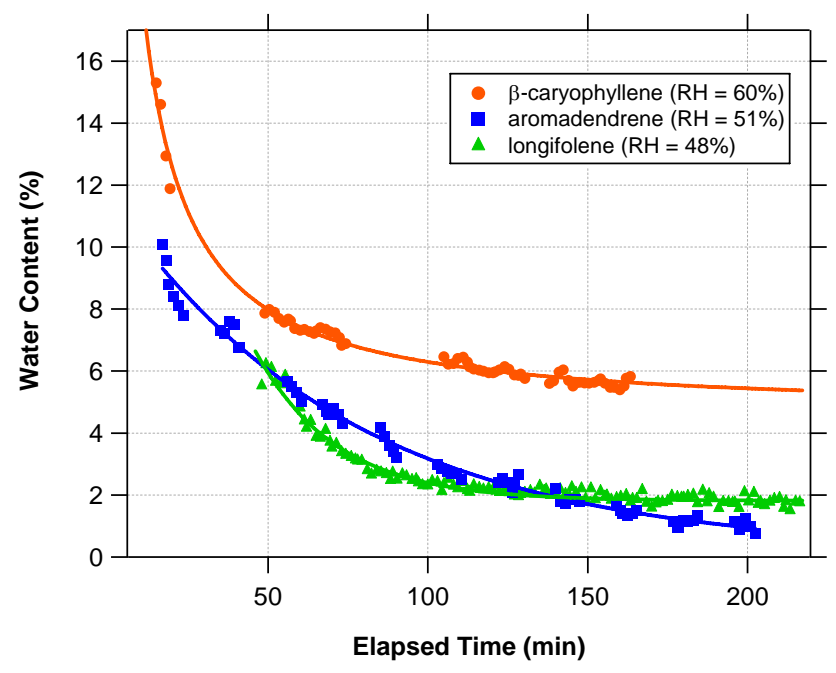

Fig. 8. The percent volumetric water content (at chamber $R H$ ) of nucleated sesquiterpene photooxidation SOA decreases with time during the experiment, suggesting that the SOA is becoming less hygroscopic. This behavior is consistent with the continued formation of less hygroscopic oligomeric species. The data shown are from 180-nm classified particles.

$\sim 4 \mathrm{~h}$. While the increase in temperature due to the UV lights does result in a slight decrease in the chamber $R H$, this reduction is generally less than $4-5 \%$ and occurs in the region where water uptake is not a strong function of $R H$. This slight decline in chamber $R H$ is not nearly large enough to account for the magnitude of the reduction in aerosol water content observed. Therefore, the diminishing percentage of water must mainly be a result of the decreasing hygroscopicity of the SOA itself. VanReken et al. (2005) reported a similar decrease in CCN activity of SOA formed from ozonolysis of various monoterpenes, which is indicative of decreasing hygroscopicity as well. Such behavior is consistent with gradual, but significant, oligomer formation in SOA, which has recently been observed even in the absence of highly acidic seed (Gao et al., 2004a, b; Kalberer et al., 2004). Oligomeric species formed by heterogeneous reactions between smaller oxidation products are expected to have lower hygroscopicity due to their high molecular weights and relatively low polarity.

While the decline in aerosol water content with time could intuitively be explained by the formation of particle-phase oligomers, it is the reverse of the trend we observed in the cycloalkene ozonolysis case, as well as in other studies previously mentioned, in which particle hygroscopicity is observed to increase with time. The increase in water uptake has generally been attributed to the further extent of organic oxidation, leading to more polar products in the particle phase. Thus, we postulate that the temporal variation in particle hygroscopicity is governed by the competing effects of formation of less hygroscopic oligomers and more 
Table 3. Summary of nucleation experiments performed and fitting results of the final hygroscopic growth curve.

\begin{tabular}{|c|c|c|c|c|c|c|c|c|c|c|}
\hline \multicolumn{6}{|c|}{ Experimental Conditions } & \multicolumn{3}{|c|}{$\begin{array}{l}\text { Fitting parameters } \\
\text { from Eq. } 2\end{array}$} & \multicolumn{2}{|c|}{$\begin{array}{l}\text { Growth factors } \\
\text { interpolated from } \\
\text { fit (see Fig. 16) }\end{array}$} \\
\hline $\begin{array}{c}\text { Parent } \\
\text { Hydrocarbon }\end{array}$ & $\begin{array}{c}\Delta H C^{\mathrm{a}} \\
(\mathbf{p p b})\end{array}$ & $\begin{array}{c}\mathbf{T} \\
(\mathbf{K})\end{array}$ & $\begin{array}{l}\text { RH } \\
(\%)\end{array}$ & $\begin{array}{c}\text { Peak } \\
\Delta M_{O}{ }^{b} \\
\left(\mu g / m^{3}\right)\end{array}$ & $\begin{array}{l}\text { SOA } \\
\text { Yield }\end{array}$ & $A$ & $\boldsymbol{B}$ & $C$ & $\begin{array}{c}\text { GF @ } \\
50 \%\end{array}$ & $\begin{array}{c}\text { GF@ } \\
85 \%\end{array}$ \\
\hline \multicolumn{11}{|c|}{ Cycloalkenes (ozonolysis in dry chamber) } \\
\hline cyclopentene & 192 & 294 & 6 & 17 & 0.031 & 0.4428 & 0.0841 & 1.2347 & 1.049 & 1.159 \\
\hline cyclohexene & 151 & 293 & 3 & 60 & 0.116 & 0.5410 & 0.0519 & 0.9920 & 1.038 & 1.123 \\
\hline cycloheptene & 170 & 293 & 6 & 78 & 0.115 & 0.3842 & 0.0759 & 1.7102 & 1.030 & 1.119 \\
\hline cyclooctene & 177 & 293 & 2 & 160 & 0.197 & 0.1025 & 0.1269 & 2.3475 & 1.027 & 1.105 \\
\hline \multicolumn{11}{|c|}{ Substituted cycloalkenes \& related compounds (ozonolysis in dry chamber) } \\
\hline $\begin{array}{l}\text { 1-methyl } \\
\text { cyclohexene }\end{array}$ & 159 & 293 & 6 & 170 & 0.267 & 0.2817 & 0.0674 & 1.7026 & 1.025 & 1.087 \\
\hline $\begin{array}{l}\text { 3-methyl } \\
\text { cyclohexene }\end{array}$ & 178 & 293 & 6 & 80 & 0.112 & 0.3152 & 0.0703 & 1.4334 & 1.032 & 1.101 \\
\hline $\begin{array}{l}\text { 1-methyl } \\
\text { cycloheptene }\end{array}$ & 188 & 293 & 3 & 450 & 0.522 & 0.1263 & 0.1095 & 2.2474 & 1.025 & 1.097 \\
\hline terpinolene & 200 & 294 & 2 & 195 & 0.172 & 0.4135 & 0.0646 & 1.6842 & 1.027 & 1.108 \\
\hline \multicolumn{11}{|c|}{ Sesquiterpenes (photooxidation in humid chamber) } \\
\hline$\alpha$-humulene & 46 & 294 & 54 & 254 & 0.65 & 0.0000 & 0.0611 & 3.4509 & 1.006 & 1.035 \\
\hline$\beta$-caryophyllene & 37 & 295 & 57 & 210 & 0.68 & 0.0000 & 0.0588 & 2.4384 & 1.011 & 1.040 \\
\hline aromadendrene & 34 & 294 & 47 & 87 & 0.374 & 0.3329 & 0.0258 & 2.0226 & 1.008 & 1.035 \\
\hline longifolene & 34 & 294 & 50 & 149 & 0.649 & $\mathrm{~N} / \mathrm{A}^{\mathrm{c}}$ & $\mathrm{N} / \mathrm{A}^{\mathrm{c}}$ & $\mathrm{N} / \mathrm{A}^{\mathrm{c}}$ & $1.010^{\mathrm{d}}$ & $1.010^{\mathrm{d}}$ \\
\hline \multicolumn{11}{|c|}{$\begin{array}{l}\text { a: Cycloalkene } \triangle H C \text { is measured by GC-FID. Terpene } \triangle H C \text { is measured by PTR-MS } \\
\text { b: measured by AMS in total MS mode } \\
\text { c: The hygroscopic growth curve could not be fitted with Eq. } 1 \text { due to irregular shape (see text for details) } \\
\text { d: GF interpolated from a fifth-order polynomial fit: GF }=1.0112-(2.17 \mathrm{e}-3 * \mathrm{RH})+\left(1.40 \mathrm{e}-4 * \mathrm{RH}^{2}\right)-\left(3.48 \mathrm{e}-6^{*} \mathrm{RH}^{3}\right)+ \\
\left(3.63 \mathrm{e}-8^{*} \mathrm{RH}^{4}\right)-\left(1.32 \mathrm{e}-10 * \mathrm{RH}^{5}\right)\end{array}$} \\
\hline
\end{tabular}

hygroscopic polar oxidized species. It appears that in the case of SOA from photooxidized sesquiterpenes, oligomer formation dominates, either in terms of relative formation rate or the absolute amount. It is unlikely that the nature of our measurement, i.e., drying wet particles to extract hygroscopicity data rather than humidifying dry particles as is commonly done, should introduce any undue artifacts such that the temporal trend would be reversed. As discussed below, the sesquiterpene SOA growth factor is not found to be a function of particle size; thus, we can also eliminate the possibility that the decreasing water content at a certain particle size could stem from smaller particles with a vastly different organic chemical composition growing into the classified size bin.

After particle nucleation has stopped and the particle growth has reached the maximum (about $4-5 \mathrm{~h}$ after inception of photooxidation), the HTDMA $R H$ is varied using both the drying and humidification systems. The growth factor, defined relative to the final dried particle diameter, is independent of the classified particle size, as shown in Fig. 9. This suggests that the aerosol chemical composition does not vary with particle size, which agrees with one's intuition about the system. Thus, we can combine the $G F$ results from any classified size into one single hygroscopic growth curve. Figure 10 shows the hygroscopic growth curves of the four sesquiterpenes studied. In general, sesquiterpene SOA has very low hygroscopicity, showing smooth but very small water uptake, with growth factors between $1.01-1.04$ at $85 \%$ $R H$. The shapes of the curves for SOA from $\alpha$-humulene, $\beta$ caryophyllene, and aromadendrene are similar, but that for longifolene exhibits an unexpected behavior, in which the increase in $G F$ with $R H$ is not monotonic. This could be indicative of the presence of void volumes in the particle, which can lead to compaction of the structure after a certain degree of water uptake. This type of behavior has been observed for nucleated particles from the photolysis of $\mathrm{CH}_{2} \mathrm{I}_{2}$, a compound emitted by marine microalgae, in the presence of ozone (Jimenez et al., 2003). However, the degree of compaction following humidification is much higher for $\mathrm{CH}_{2} \mathrm{I}_{2}$ aerosol, which is composed of highly fractal agglomerates. For longifolene, the void volume hypothesis is also consistent with the atypical observation that the precursor concentration in the chamber continues to decrease at the end of the experiment without detectable change in aerosol volume as 


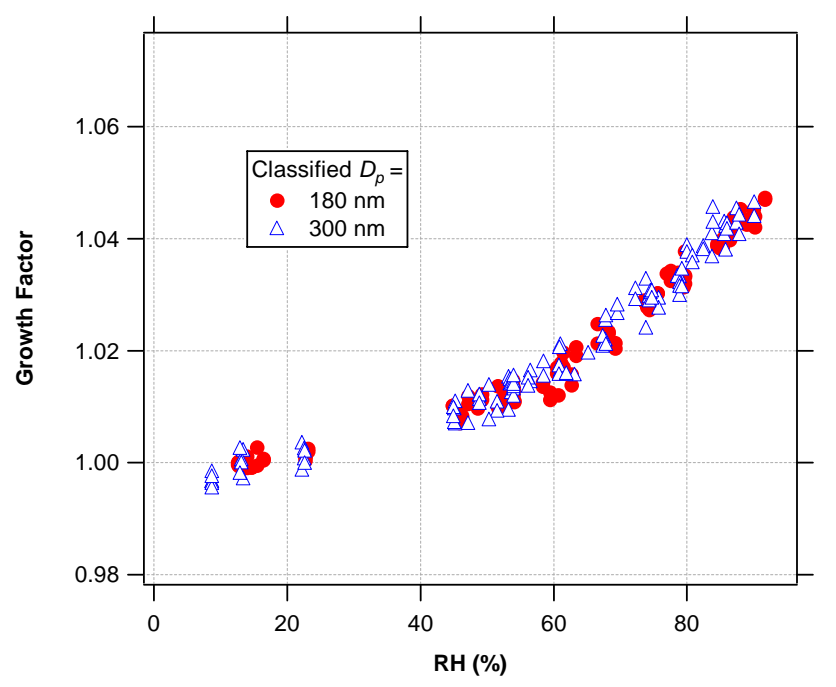

Fig. 9. Different classified diameters of pure $\beta$-caryophyllene photooxidation SOA exhibit similar hygroscopic growth factors, suggesting that the aerosol composition is independent of particle size.

measured by the DMA. If there are void volumes in a particle, additional aerosol mass can condense into those voids, resulting in denser particles with no change in apparent volume. We cannot explain, however, why only longifolene forms particles with such properties.

Fitting of the sesquiterpene hygroscopic growth curves are also performed using Eq. (2). For longifolene, a fifth-order polynomial can satisfactorily fit the experimental data. All fit parameters and interpolated $G F$ at reference $R H$ s are presented in Table 3.

\subsubsection{Monoterpenes and oxygenated terpenes - SOA on in- organic seed}

For the photooxidation of monoterpenes and oxygenated terpenes, wet $\left(\mathrm{NH}_{4}\right)_{2} \mathrm{SO}_{4}$ seed is used to provide a substrate onto which the organic oxidation products can condense. The HTDMA is still operated in the drying mode at the beginning of the experiment, allowing us to obtain the water content as in the sesquiterpene case. The percentage starts out as that of the pure $\left(\mathrm{NH}_{4}\right)_{2} \mathrm{SO}_{4}$ seed at the chamber $\mathrm{RH}$ and then decreases as the less-hygroscopic organics are deposited on the aerosol (Fig. 2b and Fig. 11). As mentioned earlier, a bimodal distribution of the aerosol following change in the $R H$ is not observed at early times as in the case of cycloalkene ozonolysis SOA grown droplets.

In the terpene oxidation experiments, because the seed aerosol is deliquesced and the chamber $\mathrm{RH}$ does not drop below the efflorescence point of $\left(\mathrm{NH}_{4}\right)_{2} \mathrm{SO}_{4}$ of $40 \%$, the seed should remain deliquesced throughout the experiment. Therefore, the measured growth factors in the HTDMA (down to $40 \% R H$ ) include the water associated with the $\left(\mathrm{NH}_{4}\right)_{2} \mathrm{SO}_{4}$ fraction according to the "wet" or efflorescence

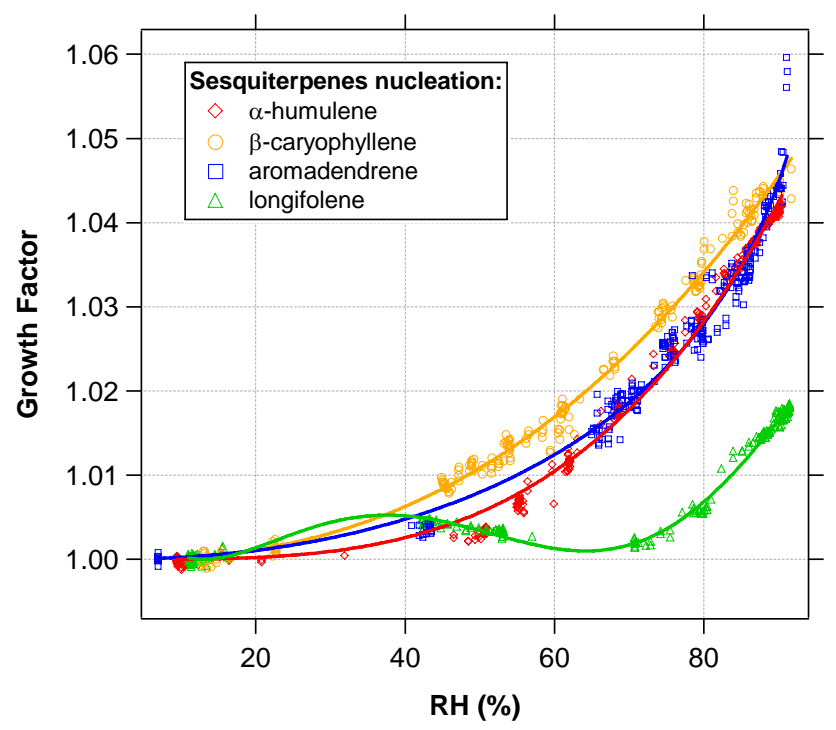

Fig. 10. Hygroscopic growth curves for nucleated SOA formed by sesquiterpene photooxidation. Sesquiterpene SOA exhibits very low hygroscopicity, showing smooth but very small water uptake, with growth factors mostly between $1.01-1.04$ at $85 \% R H$. While the shapes of the curves for SOA from $\alpha$-humulene, $\beta$ caryophyllene, and aromadendrene are similar, the curve for longifolene exhibits an unexpected behavior, in which the increase in $G F$ with $R H$ is not monotonic. This could be indicative of the presence of void volumes in the particle, which can lead to compaction of the structure after a certain degree of water uptake.

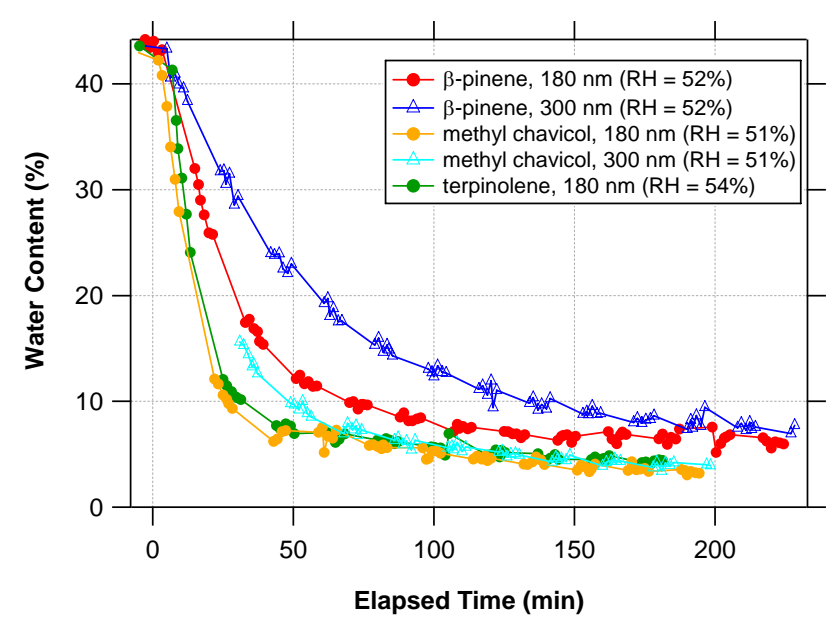

Fig. 11. The percent volumetric water content (at chamber $R H$ ) at a particular particle size of SOA formed by photooxidation of monoterpene and oxygenated terpene decreases with time early in experiment due to the deposition of less-hygroscopic organic species onto the seed. The water content levels off after a $\sim 4 \mathrm{~h}$ as the organic deposition is completed. All SOA from monoterpene and oxygenated terpene photooxidation exhibit this behavior, although only a selected few are shown here. Line between points are for guiding the eye only. 


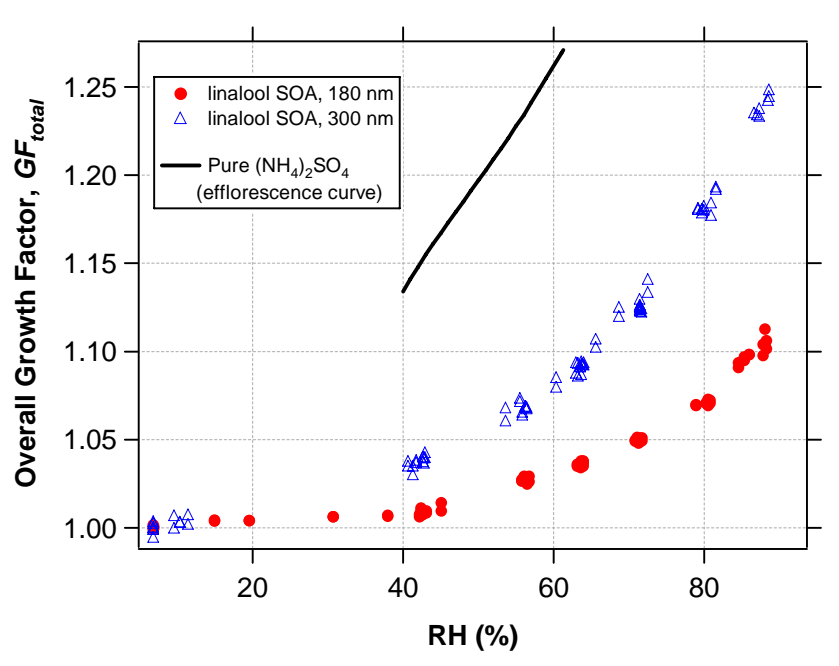

Fig. 12. Hygroscopic growth curve for linalool photooxidation SOA, measured at $180 \mathrm{~nm}$ and $300 \mathrm{~nm}$. The differing hygroscopicity reflects the different organic fractions at each size.

branch of the hysteresis curve. As shown in Fig. 12 for linalool SOA, the variation of monoterpene and oxygenated terpene SOA growth factors with $R H$ is also smooth. The 180 -nm classified particles are less hygroscopic than the 300$\mathrm{nm}$ classified particles due to the higher organic fractions in the smaller particles, but usually the difference in hygroscopicity is not as pronounced as in the illustrated case of linalool, for which the organic fractions of the 180-nm and 300-nm classified particles are more different $(0.994$ and 0.963 , respectively, see Table 5).

Figure 13 shows the raw growth curves for the suite of monoterpene and oxygenated terpene SOA studied. Reported data are from 180-nm classified diameter, unless otherwise noted. All $G F$ values from various terpene precursors are contained within a relatively narrow envelope between $1.06-1.10$ at $85 \% R H$. This agrees with the $G F$ range of $\sim 1.08-1.11$ previously reported for a few biogenic SOA (Virkkula et al., 1999; Cocker et al., 2001a, c; Saathoff et al., 2003).

In order to obtain the hygroscopic growth factor of the pure SOA portion, we must remove the effect of the inorganic seed on the overall measured growth factor. This can be achieved to first order by assuming that the water uptake by the inorganic and organic fractions is independent and additive. This is also known as the volume-weighted, volumeadditivity, or Zdanovskii-Stokes-Robinson (ZSR) assumption (Stokes and Robinson, 1966). The additivity of water associated with two different fractions is expressed as:

$G F_{\text {total }}^{3}=\varepsilon_{\text {org }} G F_{\text {org }}^{3}+\left(1-\varepsilon_{\text {org }}\right) G F_{A S}^{3}$

where $\varepsilon_{\text {org }}$ is the organic volumetric fraction, and $G F_{\text {total }}$, $G F_{\text {org }}$, and $G F_{A S}$ are the hygroscopic growth factors at a given $R H$ of the entire particle (i.e. the overall growth factor), the organic (SOA) portion, and the pure $\left(\mathrm{NH}_{4}\right)_{2} \mathrm{SO}_{4}$, respectively. We can theoretically determine $G F_{A S}$ using the ISORROPIA thermodynamic model (Nenes et al., 1998), measure $G F_{\text {total }}$ in experiment with the HTDMA, and obtain $\varepsilon_{\text {org }}$ with the AMS as described below. Using this information and Eq. (4), we can determine $G F_{\text {org }}$.

The AMS operating in time-of-flight (TOF) mode provides quantitative data on non-refractory components of aerosols as a function of size, from which we can calculate the sizedependent organic mass fraction $\varepsilon_{\mathrm{org}, m}$ as the ratio between the organic mass over the total aerosol mass:

$\varepsilon_{\text {org }, m}=\frac{M_{\text {org }}+M_{\mathrm{NO}_{3}}}{M_{\mathrm{NH}_{4}}+M_{\mathrm{SO}_{4}}+M_{\mathrm{org}}+M_{\mathrm{NO}_{3}}}$

where $M_{i}$ is the absolute mass of species $i$ measured at a given particle size. Note that we assume that nitrates measured by the AMS are fragments of organic nitrates. This assumption is supported by the observation that the nitrate signal (in total MS mode) correlates very well with the organic signal, and that both the nitrates and organics have the same mass distributions. Figure 14 shows the organic mass fraction as a function of particle size at various times during the linalool photooxidation experiment. Again, smaller particles have higher organic mass fractions due to preferential condensation of organic vapors onto smaller particles, which have higher surface area concentrations. The organic mass fraction across all sizes increases quickly as the experiment progresses and more organics condense onto the particles (Fig. 14a). The $R H$ ramp at the end of each experiment is performed when the organic fraction at a given particle size no longer changes with time, and the average organic mass fraction over the ramping time period is used in the calculation of pure SOA growth factor (black curve in Fig. 14b). Because Eq. (4) calls for an organic volumetric fraction, $\varepsilon_{\text {org }}$, we convert the AMS-derived organic mass fraction $\varepsilon_{\mathrm{org}, m}$ to $\varepsilon_{\text {org }}$ using the following relationship:

$\varepsilon_{\text {org }}=\frac{1}{1+\left(\frac{1-\varepsilon_{\text {org }, m}}{\varepsilon_{\text {org }, m}}\right)\left(\frac{\rho_{\text {org }}}{\rho_{A S}}\right)}$

where $\rho_{\text {org }}$ is the density of the pure SOA portion of the aerosol, and $\rho_{A S}$ is the density of ammonium sulfate $\left(1.77 \mathrm{~g} / \mathrm{cm}^{3}\right)$.

We note that while the HTDMA measures particle size as electrical mobility equivalent diameter, $D_{p}$, the AMS measures particle size as the vacuum aerodynamic diameter, $D_{v a}$. The electrical mobility equivalent diameter is the diameter of a spherical particle with the same electrical migration mobility at atmospheric pressure as the particle of interest. The vacuum aerodynamic diameter is defined as the diameter of a unit-density sphere having the same terminal velocity in the free-molecular regime as the particle of interest. These two measures of particle size are related by the "effective density" as (DeCarlo et al., 2004):

$D_{v a}=D_{p} \frac{\rho_{\mathrm{eff}}}{\rho_{0}}$ 


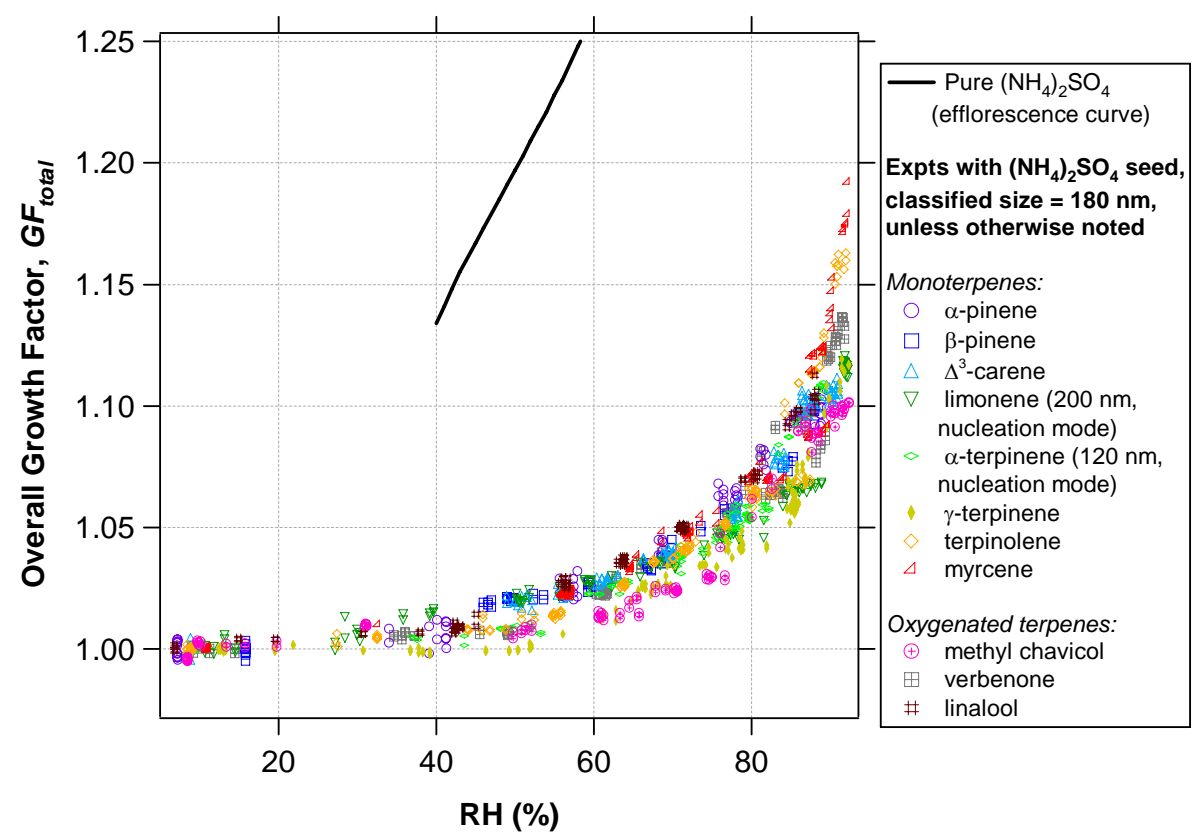

Fig. 13. Raw hygroscopic growth factors of $\mathrm{SOA}$ from monoterpene and oxygenated terpene photooxidation $\left(\mathrm{with}\left(\mathrm{NH}_{4}\right)_{2} \mathrm{SO}_{4}\right.$ seed). Reported data are from 180-nm classified diameter, unless otherwise noted. All the growth factors from various terpene precursors are contained within a relatively narrow envelope between $1.06-1.10$ at $85 \% \mathrm{RH}$.

Table 4. Effective particle density and SOA density for monoterpene and oxygenated terpene precursors used in seeded experiments, in which AMS measurements were available. The calculations of both densities are performed in the same manner as in Bahreini et al. (2005).

\begin{tabular}{lcc}
\hline \multicolumn{1}{c}{ Parent hydrocarbon } & $\begin{array}{c}\text { Effective particle } \\
\text { density, } \rho_{\text {eff }}\left(\mathbf{g} / \mathbf{c m}^{\mathbf{3}}\right)\end{array}$ & $\begin{array}{c}\text { SOA density, } \\
\rho_{\text {org }}\left(\mathbf{g} / \mathbf{c m}^{\mathbf{3}}\right)\end{array}$ \\
\hline limonene & 1.30 & 1.30 \\
\hline$\alpha$-terpinene & 1.20 & 1.20 \\
\hline terpinolene & 1.40 & 1.39 \\
\hline methyl chavicol & 1.30 & 1.28 \\
\hline verbenone & 1.30 & 1.27 \\
\hline linalool & 1.30 & 1.27 \\
\hline Average & & $\mathbf{1 . 3 0}$ \\
\hline
\end{tabular}

where $\rho_{0}=1 \mathrm{~g} / \mathrm{cm}^{3}$, and $\rho_{\text {eff }}$ is the effective density of the aerosol, which is equivalent to the true material density of the aerosol assuming particle sphericity. The effective density can be estimated by matching the AMS and the corresponding DMA volume distributions at the rising edge (Bahreini et al., 2005). The density of the pure organic portion $\rho_{\text {org }}$ can then be calculated from this $\rho_{\text {eff }}$ using simple mass-weighting. The effective density and SOA density for monoterpenes and oxygenated terpene experiments for which AMS measurements are available are listed in Table 4. These values are used to convert between the AMS-based $D_{v a}$ and HTDMA-based $D_{p}$. Thus, the organic mass fractions at the final HTDMA-dried particle sizes of $178 \mathrm{~nm}$ and $291 \mathrm{~nm}$ (for linalool experiment) are taken at AMS vacuum aerodynamic diameters of $232 \mathrm{~nm}$ and $378 \mathrm{~nm}$, respectively, as shown by vertical dashed lines in Fig. 14b. 
Table 5. Summary of experiments with $\left(\mathrm{NH}_{4}\right)_{2} \mathrm{SO}_{4}$ seed and the fitting results of the hygroscopic growth curve. Pure SOA growth factors $\left(G F_{\text {org }}\right)$ are calculated from measured organic fractions at different TDMA-classified sizes.

\begin{tabular}{|c|c|c|c|c|c|c|c|c|c|c|c|c|c|}
\hline \multicolumn{8}{|c|}{ Experimental Conditions } & \multicolumn{3}{|c|}{$\begin{array}{l}\text { Fitting parameters } \\
\text { from Eq. } 2\end{array}$} & \multicolumn{2}{|c|}{$\begin{array}{l}\text { GF interpolated } \\
\text { from fit (Fig. 16) }\end{array}$} & \multirow[b]{2}{*}{$\Delta G F_{c}$} \\
\hline $\begin{array}{l}\text { Parent } \\
\text { Hydro- } \\
\text { carbon }\end{array}$ & $\begin{array}{l}\Delta H C \\
(\mathbf{p p b})\end{array}$ & $\begin{array}{c}\mathbf{T} \\
(\mathbf{K})\end{array}$ & $\begin{array}{l}\text { RH } \\
(\%)\end{array}$ & $\begin{array}{c}\text { Peak } \\
\Delta M_{O}^{\text {a }} \\
\left(\mu \mathrm{g} / \mathbf{m}^{3}\right)\end{array}$ & $\begin{array}{l}\text { SOA } \\
\text { Yield }\end{array}$ & $\begin{array}{l}D_{p, \text { classified }} \\
(\mathbf{n m})\end{array}$ & $\varepsilon_{o r g}$ & $A$ & $\boldsymbol{B}$ & $C$ & $\begin{array}{c}\text { GF @ } \\
\mathbf{5 0} \%\end{array}$ & $\begin{array}{l}\text { GF @ } \\
85 \%\end{array}$ & \\
\hline \multicolumn{14}{|c|}{ Monoterpenes (photooxidation in humid chamber) } \\
\hline \multirow{2}{*}{$\alpha$-pinene } & \multirow{2}{*}{108} & \multirow{2}{*}{293} & \multirow{2}{*}{44} & \multirow{2}{*}{$199^{\mathrm{b}}$} & \multirow{2}{*}{0.337} & 180 & $0.996^{\mathrm{d}}$ & 0.0000 & 0.1447 & 3.2783 & 1.015 & 1.085 & \multirow{2}{*}{0.004} \\
\hline & & & & & & 300 & $0.982^{d}$ & 0.0000 & 0.1443 & 3.0028 & 1.018 & 1.089 & \\
\hline \multirow{2}{*}{$\beta$-pinene } & \multirow{2}{*}{170} & \multirow{2}{*}{293} & \multirow{2}{*}{50} & \multirow{2}{*}{$293^{b}$} & \multirow{2}{*}{0.318} & 180 & $0.996^{\mathrm{d}}$ & 0.5108 & 0.0367 & 1.5177 & 1.018 & 1.076 & \multirow{2}{*}{-0.005} \\
\hline & & & & & & 300 & $0.982^{d}$ & 0.6526 & 0.0243 & 1.0138 & 1.019 & 1.071 & \\
\hline \multirow{2}{*}{$\Delta^{3}$-carene } & \multirow{2}{*}{109} & \multirow{2}{*}{294} & \multirow{2}{*}{53} & \multirow{2}{*}{$236^{\mathrm{b}}$} & \multirow{2}{*}{0.399} & 180 & $0.996^{\mathrm{d}}$ & 0.1825 & 0.0912 & 2.8905 & 1.014 & 1.081 & \multirow{2}{*}{0.000} \\
\hline & & & & & & 300 & $0.982^{d}$ & 0.0999 & 0.1098 & 3.0357 & 1.014 & 1.081 & \\
\hline \multirow{3}{*}{ limonene } & \multirow{3}{*}{120} & & & & & $200^{c}$ & 1.000 & 0.8133 & 0.0153 & 0.5882 & 1.018 & 1.065 & \\
\hline & & 294 & 45 & 435 & 0.645 & 300 & 0.999 & 0.4907 & 0.0424 & 1.2047 & 1.026 & 1.088 & 0.023 , \\
\hline & & & & & & 400 & 0.996 & 0.7191 & 0.0326 & 0.8574 & 1.030 & 1.111 & \\
\hline & & & & & & $120^{c}$ & 1.000 & 0.6083 & 0.0378 & 2.4262 & 1.011 & 1.081 & \\
\hline$\alpha$-terpinene & 103 & 293 & 47 & 217 & 0.372 & 230 & 0.990 & 0.9616 & 0.0219 & 1.5472 & 1.015 & 1.106 & 0.025 \\
\hline & & & & & & 180 & $0.996^{\mathrm{d}}$ & 0.5771 & 0.0319 & 2.8239 & 1.007 & 1.060 & \\
\hline$\gamma$-terpinene & 119 & 294 & 48 & $193^{\mathrm{b}}$ & 0.301 & 300 & $0.982^{d}$ & 0.6638 & 0.0515 & 3.0681 & 1.010 & 1.110 & 0.050 \\
\hline terninolene & 110 & 294 & 50 & $190^{\mathrm{b}}$ & & 180 & 0.990 & 0.9246 & 0.0172 & 1.5134 & 1.011 & 1.077 & \\
\hline & 110 & 294 & 50 & $190^{\circ}$ & 0.319 & 300 & 0.973 & 0.9546 & 0.0275 & 1.7925 & 1.015 & 1.126 & 0.049 \\
\hline myrcene & 112 & 294 & 53 & $272^{\mathrm{b}}$ & 0446 & 180 & $0.996^{\mathrm{d}}$ & 0.9703 & 0.0145 & 0.5806 & 1.019 & 1.083 & 0011 \\
\hline & & & 53 & $2 / 2$ & 0.446 & 300 & $0.982^{d}$ & 0.7255 & 0.0311 & 1.6379 & 1.017 & 1.094 & 0.011 \\
\hline & & & & $\mathbf{O x y}$ & genated & erpenes (pho & oxidation & n humid & amber) & & & & \\
\hline methyl & & & & & & 180 & 0.999 & 0.0000 & 0.1509 & 4.8326 & 1.005 & 1.069 & \\
\hline chavicol & 79 & 294 & 49 & 125 & 0.259 & 300 & 0.994 & 0.0000 & 0.1904 & 5.1972 & 1.005 & 1.082 & 0.013 \\
\hline yorbenome & 105 & 204 & 16 & 120 & 0109 & 180 & 0.994 & 0.4884 & 0.0453 & 2.4240 & 1.012 & 1.077 & 0040 \\
\hline verbenone & 105 & 294 & 46 & 129 & 0.198 & 300 & 0.973 & 0.9167 & 0.0268 & 1.2082 & 1.022 & 1.126 & 0.049 \\
\hline linglon & 124 & 295 & 40 & 146 & 0184 & 180 & 0.994 & 0.2092 & 0.0894 & 2.6252 & 1.017 & 1.087 & 0104 \\
\hline linalool & 124 & 295 & 40 & 146 & 0.184 & 300 & 0.963 & 0.1191 & 0.2322 & 2.5935 & 1.042 & 1.191 & 0.104 \\
\hline $\begin{array}{l}\text { a: Measured } \\
\text { b: Calculatec } \\
\text { c: At the pea } \\
\text { d: AMS data } \\
\text { of } 0.996 \text { and }\end{array}$ & AMS & total & $\mathrm{S} \mathrm{mo}$ & rode" (alre & $\begin{array}{l}\text { inene, } \triangle \\
\text { ine pure }\end{array}$ & $\begin{array}{l}\text { noted } \\
\text { average SC } \\
\text { SOA), whic } \\
\text {-carene, } \gamma \text {-t } \\
\text { assified part }\end{array}$ & formed & $\begin{array}{l}\text { of } 1.30 \mathrm{~g} \\
\text { espite the } \\
\text { d myrce } \\
\text { ctively. }\end{array}$ & $\begin{array}{l}\mathrm{m}^{3} \text { from } \\
\text { resence } 0 \\
\text { experim }\end{array}$ & $\begin{array}{l}\text { MS } \\
\text { seed } \\
\text { ts. The }\end{array}$ & ( & - & tions \\
\hline
\end{tabular}

The resulting organic volume fractions at different classified sizes are reported in Table 5. The relatively high $\varepsilon_{\text {org }}$ values $(0.990-1.000$ at $180-\mathrm{nm}$ classified size) indicate that the SOA selected by the HTDMA is almost entirely composed of organics, with a virtually negligible $\left(\mathrm{NH}_{4}\right)_{2} \mathrm{SO}_{4}$ core. Even the 300-nm particles have relatively high organic fractions $(0.963-0.999)$. Thus, $G F_{\text {total }}$ is already a relatively accurate approximation of $G F_{\text {org }}$ even without explicit volumeweighting analysis. For completeness, however, we will proceed with determination of $G F_{\text {org }}$ according to Eq. (4).

Figure 15 shows the original hygroscopic growth curves (with inorganic seed) and the calculated $G F_{\text {org }}$ curves from different classified diameters of (a) $\Delta^{3}$-carene SOA, (b) linalool SOA, and (c) limonene SOA. The $G F_{\text {org }}$ curves are seen as "shifted" downward when the water uptake of $\left(\mathrm{NH}_{4}\right)_{2} \mathrm{SO}_{4}$ is taken into account using Eq. (4). However, while it is expected that the $G F_{\text {org }}$ curves calculated from the different classified diameters would collapse together, this may occur to varying degrees. For $\Delta^{3}$-carene SOA (Fig. 15a), the $G F_{\text {org }}$ curves calculated from $180-\mathrm{nm}$ or $300-$ $\mathrm{nm}$ classified sizes are practically identical. For linalool SOA (Fig. 15b), there is a large discrepancy between the two curves. For the limonene SOA (Fig. 15c), we are able to directly measure $G F_{\text {org }}$ by classifying 200 -nm particles, which are in a small mode grown from particles that nucleated despite the presence of seed. The figure illustrates that the $G F_{\text {org }}$ values calculated from the $300 \mathrm{~nm}$ and $400 \mathrm{~nm}$ classified sizes are close to the directly measured $G F_{\text {org }}$ at the pure organic mode at $200 \mathrm{~nm}$, but not exactly equal. The possible reasons for this variation in the ability to match $G F_{\text {org }}$ curves derived from different classified sizes are discussed below. Each obtained $G F_{\text {org }}$ curve can still be fitted with the threeparameter functional form of Eq. (2). Table 5 lists the resulting fit parameters and the interpolated $G F_{\text {org }}$ at reference $R H \mathrm{~s}$ from different classified diameters for monoterpene and oxygenated terpene experiments. In general, the growth factors for pure monoterpene and oxygenated terpene SOA are between 1.06-1.11, which is practically identical to the raw growth data when the $\left(\mathrm{NH}_{4}\right)_{2} \mathrm{SO}_{4}$ growth is not taken into account. This range is higher than that for sesquiterpene SOA 

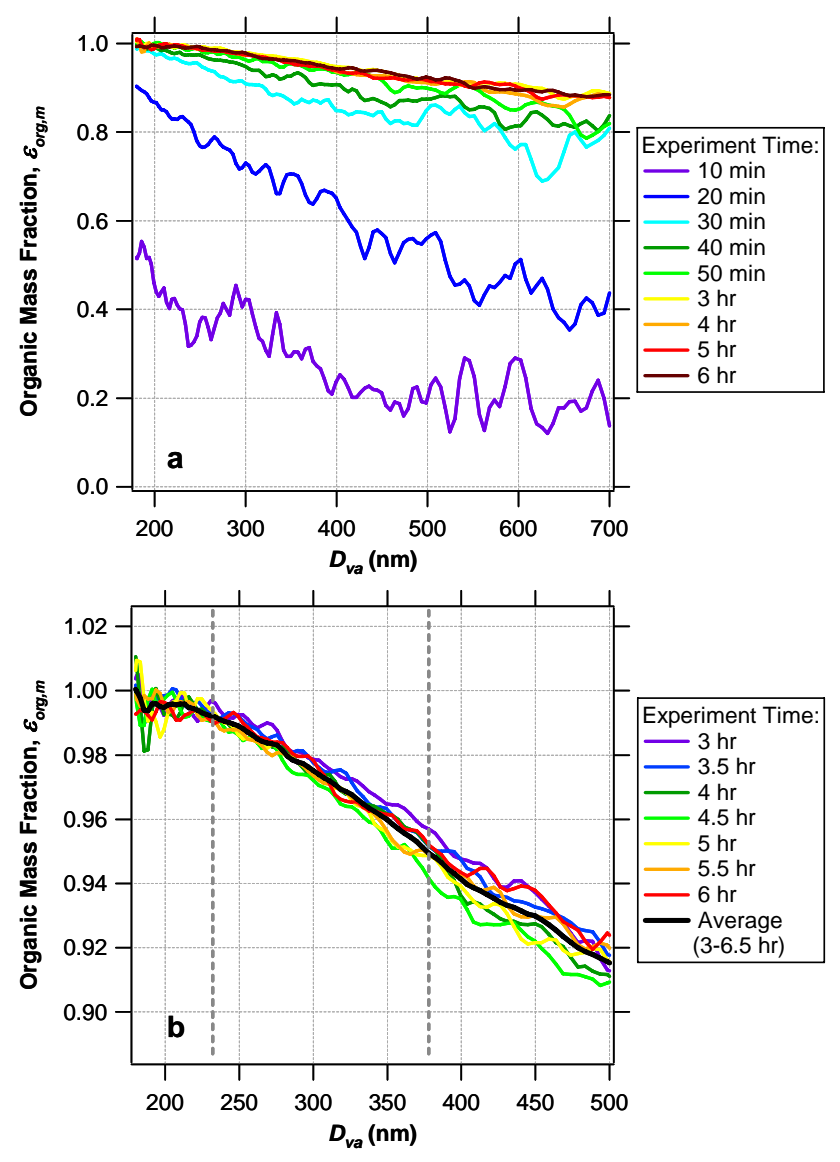

Fig. 14. Size-dependent organic mass fraction vs. particle vacuum aerodynamic diameter, as measured by the AMS at various times during linalool photooxidation experiment. Smaller particles have higher organic mass fractions due to preferential condensation of organic vapors onto smaller particles, which have higher surface area concentration. The organic mass fraction across all sizes increases as the experiment progresses and more organics condense onto the particles. (a) The organic fraction curves shown at times less than $1 \mathrm{~h}$ are calculated by averaging $4 \mathrm{~min}$ of AMS data, while those at times more than $1 \mathrm{~h}$ are calculated by averaging $30 \mathrm{~min}$ of data. (b) TDMA ramping for this linalool experiment occurs between $3-7 \mathrm{~h}$, when the organic fraction at a given size no longer changes with time, and the average organic mass fraction over this long time is used in the calculation of pure SOA growth factor (intersection between the black average curve and the dashed line showing classified sizes at $D_{v a}=232 \mathrm{~nm}$ and $378 \mathrm{~nm}$ ).

$(G F=1.01-1.04)$, which is intuitive due to the higher molecular weights of sesquiterpene precursors. Larger precursors should produce larger oxidation products, which given the same functionalities would tend to be less hygroscopic.

One possible cause for the finding that $G F_{\text {org }}$ values calculated from different classified diameters do not fall onto a single curve for certain SOA precursors is inaccuracy of the volume-weighting approach to describe water uptake of an inorganic-organic mixture. The method has been shown
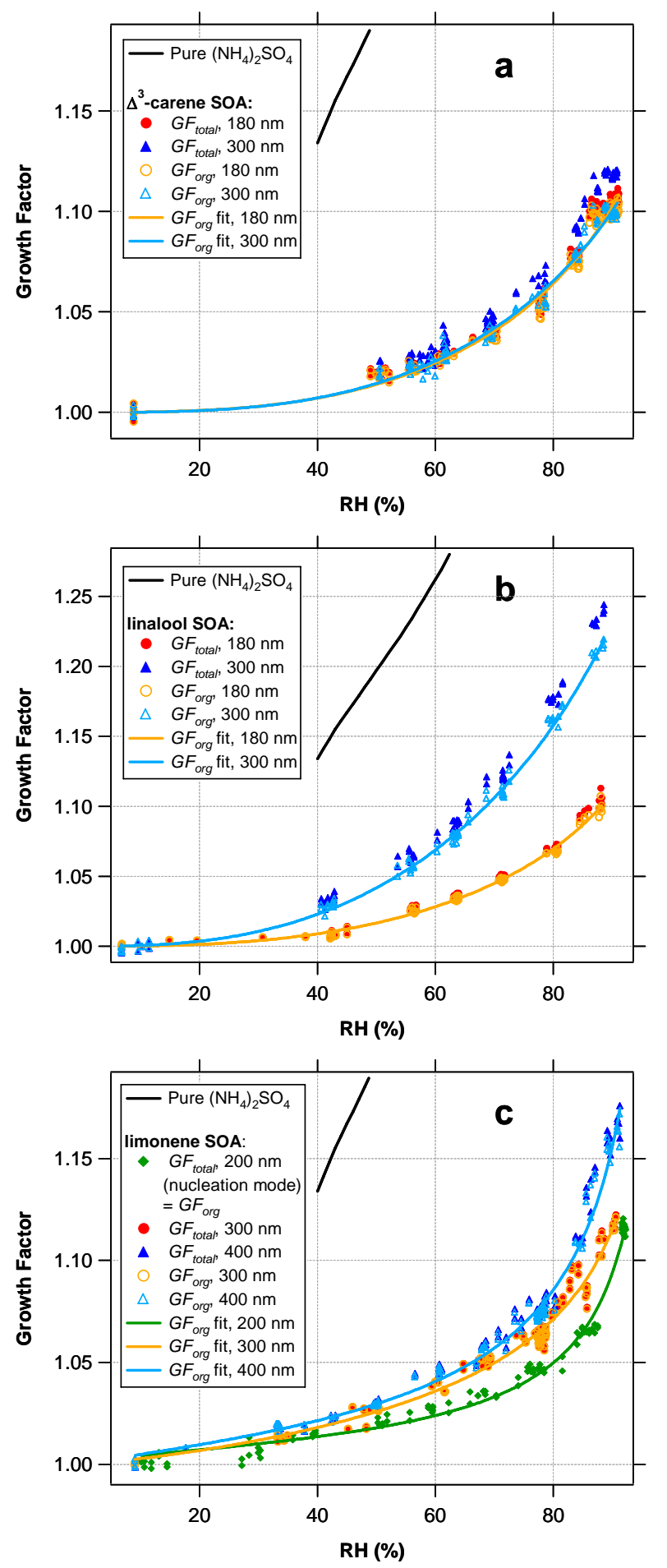

Fig. 15. Hygroscopic growth curves of (a) $\Delta^{3}$-carene, (b) linalool, and (c) limonene photooxidation SOA, with and without accounting for the effect of water uptake by inorganic seed. For a given precursor, the resulting "pure SOA" growth curves from the different classified sizes collapse together to various degrees. Possible reasons for this behavior are discussed in the text. 
to work with relatively dilute solutions, where the inorganic and organic species do not thermodynamically interact with each other (Choi and Chan, 2002; Prenni et al., 2003; Wise et al., 2003). However, the SOA we are studying has very high organic fractions and correspondingly low water content, and thus could involve some non-ideal solution thermodynamics, the effect of which may not be captured by the assumption of volume additivity. Khlystov et al. (2005) also reported discrepancies between measured water content of ambient aerosol and that predicted by the ZSR method. The authors used models that assumed organics do not contribute to water absorption and only took into account the water uptake by inorganics. Their results indicate that the models underestimated the water uptake compared to the measured values; however, no correlation was found between the organic mass and the scaled excess water (measured minus predicted). This indicates that volume additivity may not apply, and complex interactions between the organic and inorganics may be occurring, leading to the water uptake of the inorganic portion being enhanced or suppressed. On the other hand, our mixed particles have very low inorganic content to add to the solute amount, and the organic oxidation products are not likely to be nearly as soluble in water as $\left(\mathrm{NH}_{4}\right)_{2} \mathrm{SO}_{4}$. A first-order calculation, using pinonic acid as a model compound to represent particle-phase oxidation products, suggests that the solution molality would be on the order of 0.02 molal. While the molality could potentially be an order of magnitude or so higher depending on the organic composition and solubility, it is likely not large enough to be in the regime where organic/inorganic interactions could become significant.

For ease of discussion, we define the discrepancy $\Delta G F_{c}$ between the $G F_{\text {org }}$ at $85 \%$ derived from different classified sizes (nominally 300 and $180 \mathrm{~nm}$ ) as follows:

$\Delta G F_{c}=G F_{\text {org }, 300 \mathrm{~nm}}-G F_{\text {org }, 180 \mathrm{~nm}}$

Linalool, $\gamma$-terpinene, terpinolene, and verbenone are the precursors that show significantly different $G F_{\text {org }}$ derived from different classified sizes $\left(\Delta G F_{c}>0.04\right)$, while $\alpha$ pinene, $\beta$-pinene, $\Delta^{3}$-carene, myrcene, and methyl chavicol are those whose $G F_{\text {org }}$ curves from different classified sizes agree well with each other $\left(\Delta G F_{c}<0.015\right)$. Limonene and $\alpha$-terpinene exhibit deviations that are in between these two extremes. Note that the compounds with high $\Delta G F_{c}$ tend to also show relatively different raw growth curves from 180$\mathrm{nm}$ and $300-\mathrm{nm}$ classified sizes. The corresponding $\varepsilon_{\text {org }}$ at the two sizes are also more different than with other compounds. If either the AMS overestimates the organic fraction of larger particles or the HTDMA overestimates $G F$ at the larger sizes or underestimates $G F$ at smaller sizes, this would result in higher $\Delta G F_{c}$.

Since we utilize the size-resolved organic fraction data derived from the AMS, we are also subject to the uncertainties inherently present in AMS measurements and the assumptions made in the analysis that can manifest into errors in the $G F_{\text {org }}$ calculation, for example, uncertainties in collection efficiency due to bounce of particles on the AMS vaporizer, the relative ionization efficiency used for organic species, handling of interferences due to organic nitrates, or using a unity shape factor (i.e. assuming particle sphericity) when interpreting the mass distributions. All of these could potentially impact the estimated speciated mass; however, because the organic fraction is expressed as a ratio between the organic and total mass, the errors affecting absolute mass must be quite large in order to impact the organic fraction significantly. To match the $G F_{\text {org }}$ curves from two classified sizes for linalool, for example, $\varepsilon_{\text {org }}$ at $300 \mathrm{~nm}$ would need to be $\sim 0.83$ rather than 0.963 , which is well outside the measurement uncertainty of the AMS. At the same time, the growth curves for the two sizes as measured by the HTDMA (Fig. 12) are also quite different and beyond the measurement uncertainty of the HTDMA ( \pm 0.02 in $G F$, from the deviation of observed vs. theoretical pure growth curves). Although another possible reason for the high $\Delta G F_{c}$ is that different organic species condense onto seeds of different size ranges, this would seem unlikely.

\subsection{Mass transfer considerations}

In any hygroscopic growth measurement, one must also consider the possibility that the aerosol measured is not at equilibrium with the new $R H$. While mass transfer analysis shows that sub-micrometer particles only require time scales of less than a second to attain equilibrium sizes following humidification or dehumidification (Kerminen, 1997), it has been suggested that an organic layer present on the particle may reduce the rate of water transport across the surface by acting as a physical barrier (Xiong et al., 1998; Chuang, 2003). If insufficient time is allowed for particles to achieve their final sizes in the $R H$ conditioner and mixing chamber, in which particle growth or evaporation is induced, the size distribution attained by the time the particles are sized in the scanning DMA may not be the equilibrium size distribution. However, this is unlikely to be the cause of the noncollapsing $G F_{\text {org }}$ curves because the organic fractions for all types and sizes of SOA are consistently high. The difference between organic layer thicknesses corresponding to organic fractions of 0.963 and 0.994 is negligible, and it is unlikely that only particles of a certain classified size in the HTDMA would suffer from mass transfer limitation but not at another size.

In addition, it has been shown that the characteristic diffusion time scale for gas-phase species (such as of water vapor) to a particle, the time scale to achieve equilibrium in the gas-particle interface, and the time scale of aqueous-phase diffusion in a droplet all vary with the square of the particle diameter (Seinfeld and Pandis, 1998). Thus, if mass transfer limitation occurs in the particles we study, a 300 -nm particle should suffer a delay in growth that is $\sim 2.8$ times as long as that of a $180-\mathrm{nm}$ particle. The very slightly lower absolute 
organic fractions in the larger particle would not be low enough to alleviate the greater mass transfer delay. Therefore, if mass transfer limitation was a factor in our measurements, we would expect that, relative to the $180-\mathrm{nm}$ particles, the 300-nm particles would not reach a sufficiently large final droplet size when exposed to the same elevated humidity. On the contrary, for the four compounds with the disagreement behavior, $G F_{\text {org }}$ values calculated from 300 -nm classified particles are consistently greater than those from 180$\mathrm{nm}$ particles, indicating that the $300-\mathrm{nm}$ particles "grew too much", reaching larger final size change ratios than would be expected when comparing to $180-\mathrm{nm}$ particles of similar organic fraction. This is the opposite trend as would be expected for a mass-transfer-limited case. Hence, we believe that mass transfer limitations are not an issue in our HTDMA for the current study. As such, we do not currently have a likely explanation for the discrepancy between the $G F_{\text {org }}$ derived from different classified sizes in certain compounds.

\subsection{Comparison of growth factors from various systems}

To explain the growth factors from the various precursor compounds, we attempt to correlate $G F_{\text {org }}$ with features of the precursor. Figure 16 shows the SOA growth factors at $50 \%$ and $85 \% R H$ plotted against (a) the precursor molecular weight and (b) the organic mass yield from the nucleated cycloalkene ozonolysis and sesquiterpenes photooxidation SOA, and monoterpene and oxygenated terpene photooxidation SOA on $\left(\mathrm{NH}_{4}\right)_{2} \mathrm{SO}_{4}$ seed. For the latter case, $G F_{\text {org }}$ calculated from the lowest classified size is shown. The peak organic mass yield $Y$ is defined as the ratio of the mass of the organics formed $\left(\Delta M_{O}\right)$ to the mass of the parent hydrocarbon consumed $(\triangle H C)$ during the experiment:

$Y=\frac{\Delta M_{O}}{\Delta H C}$

For experiments in which AMS data are available, $\Delta M_{O}$ is taken from the peak total organic signal. Otherwise, it is calculated from the DMA-derived total aerosol volume change, multiplied by the averaged terpene SOA density of $1.30 \mathrm{~g} / \mathrm{cm}^{3}$. At both reference $R H \mathrm{~s}$, we observe a general anti-correlation between $G F_{\text {org }}$ and both precursor molecular weight and SOA yield. This is understandable because higher-molecular weight precursors will tend to produce larger oxidation products, which are less hygroscopic given similar functional groups. Since the larger oxidation products also tend to be less volatile, they also result in higher SOA yields.

\section{Conclusions}

The hygroscopic growth of SOA formed by ozonolysis of cycloalkenes and photooxidation of sesquiterpene and monoterpenes is studied. In all cases, the SOA are slightly hygroscopic, but considerably less so than inorganic salts
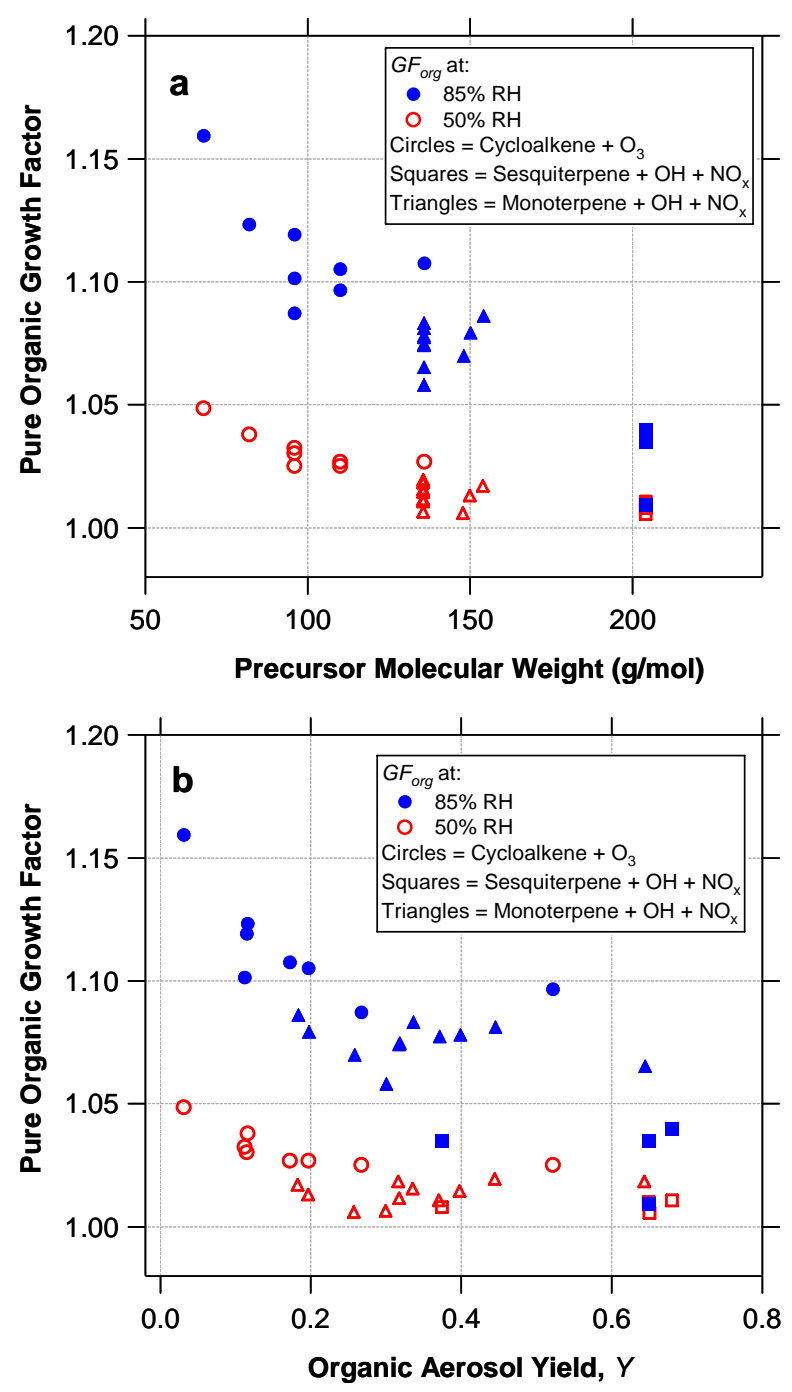

Fig. 16. SOA growth factor versus (a) the molecular weight and (b) the SOA yield of the precursor.

such as $\left(\mathrm{NH}_{4}\right)_{2} \mathrm{SO}_{4}$, and show smooth water uptake curves with no deliquescence or efflorescence behavior. In the seeded cycloalkene experiments, bimodal droplet distributions are observed early in the experiment, due to the differing organic mass fractions in monodisperse particles caused by different particle growth trajectories. In cycloalkene nucleation experiments, the water uptake is seen to increase with time, indicative of further oxidation of organic products into more polar and more hygroscopic species. For the SOA formed by photooxidation of sesquiterpene SOA, however, the hygroscopicity decreases with time, which could be explained by the formation of higher-molecular weight and less hydrophilic oligomers. Thus, the temporal variation of SOA hygroscopicity is probably a result of these two competing effects.

The SOA growth factor as a function of $R H$ is measured, and the growth curve is fitted with an empirical three- 
parameter functional form, from which the $G F$ at any $R H$ can be interpolated. $G F$ values of the pure organic portion of the SOA at $85 \% R H$ are between 1.09-1.16 for the $\mathrm{C}_{5}-\mathrm{C}_{8}$ cycloalkenes, $1.06-1.10$ for the monoterpenes and oxygenated terpenes, and 1.01-1.04 for the sesquiterpenes. In the monoterpene and oxygenated terpene case, volumeweighting analysis is performed to compute the growth factor of the pure SOA from the growth measured with inorganic seed. This approach results in mixed success as observed by the pure organic growth curves from different classified sizes agreeing to varying degrees. Finally, we observe an anti-correlation between the pure SOA growth factor and the precursor molecular weight and SOA yield that is consistent with the fact that higher-molecular weight precursors tend to produce larger, less hygroscopic oxidation products.

The implication of these measurements to modeling of atmospheric aerosol is that the presence of SOA in a particle can significantly reduce the hygroscopicity of the aerosol at high $R H \mathrm{~s}$ from that for pure inorganics. We find the SOA to lack a clear deliquescence $R H$ and to continually uptake water even at $R H$ s lower than the deliquescence $R H$ of atmospherically relevant inorganic substances. These observations suggest that SOA can play an important role in extending the range of $R H \mathrm{~s}$ over which particle-bound water influences aerosol physicochemical and optical properties.

Acknowledgements. This research was funded by the U.S. Environmental Protection Agency Science to Achieve Results (STAR) Program grant number RD-83107501-0, managed by EPA's Office of Research and Development (ORD), National Center for Environmental Research (NCER), and by U.S. Department of Energy Biological and Environmental Research Program DE-FG0205ER63983. The University of California contributions to this work were supported by the National Science Foundation Atmospheric Chemistry Program (Awards ATM-0119510 and ATM0443448) and the California Air Resources Board (Contract 00732). F. J. Brechtel was supported by the National Science Foundation Atmospheric Chemistry Program under Award ATM0333817. The authors thank D. Collins of Texas A\&M University and C. Stanier of University of Iowa for helpful discussions.

Edited by: T. Koop

\section{References}

Allan, J. D., Alfarra, M. R., Bower, K. N., Williams, P. I., Gallagher, M. W., Jimenez, J. L., McDonald, A. G., Nemitz, E., Canagaratna, M. R., Jayne, J. T., Coe, H., and Worsnop, D. R.: Quantitative sampling using an Aerodyne aerosol mass spectrometer - 2. Measurements of fine particulate chemical composition in two U.K. cities, J. Geophys. Res.-Atmos., 108, 4091, doi:10.1029/2002JD002359, 2003.

Andreae, M. O. and Crutzen, P. J.: Atmospheric aerosols: Biogeochemical sources and role in atmospheric chemistry, Science, 276, 1052-1058, 1997.

Ansari, A. S. and Pandis, S. N.: Water absorption by secondary organic aerosol and its effect an inorganic aerosol behavior, Environ. Sci. Technol., 34, 71-77, 2000.
Bahreini, R., Keywood, M. D., Ng, N. L., Varutbangkul, V., Gao, S., Flagan, R. C., Seinfeld, J. H., Worsnop, D. R., and Jimenez, J. L.: Measurements of secondary organic aerosol from oxidation of cycloalkenes, terpenes, and m-xylene using an Aerodyne aerosol mass spectrometer, Environ. Sci. Technol., 39, 5674-5688, 2005.

Baltensperger, U., Kalberer, M., Dommen, J., Paulsen, D., Alfarra, M. R., Coe, H., Fisseha, R., Gascho, A., Gysel, M., Nyeki, S., Sax, M., Steinbacher, M., Prevot, A. S. H., Sjoren, S., Weingartner, E., and Zenobi, R.: Secondary organic aerosols from anthropogenic and biogenic precursors, Faraday Discuss., 130, 265-278, doi:10.1039/b417367h, 2005.

Broday, D. M. and Georgopoulos, P. G.: Growth and deposition of hygroscopic particulate matter in the human lungs, Aerosol Sci. Technol., 34, 144-159, 2001.

Busch, B., Kandler, K., Schutz, L., and Neusüss, C.: Hygroscopic properties and water-soluble volume fraction of atmospheric particles in the diameter range from $50 \mathrm{~nm}$ to $3.8 \mu \mathrm{m}$ during LACE 98, J. Geophys. Res.-Atmos., 107, 8119, doi:10.1029/2000JD000228, 2002.

Cabada, J. C., Pandis, S. N., and Robinson, A. L.: Sources of atmospheric carbonaceous particulate matter in Pittsburgh, Pennsylvania, J. Air Waste Manage. Assoc., 52, 732-741, 2002.

Cabada, J. C., Pandis, S. N., Subramanian, R., Robinson, A. L., Polidori, A., and Turpin, B.: Estimating the secondary organic aerosol contribution to PM2.5 using the EC tracer method, Aerosol Sci. Technol., 38, 140-155, 2004.

Chan, H. K., Eberl, S., Daviskas, E., Constable, C., and Young, I.: Changes in lung deposition of aerosols due to hygroscopic growth: A fast SPECT study, Journal of Aerosol MedicineDeposition Clearance and Effects in the Lung, 15, 307-311, 2002.

Choi, M. Y. and Chan, C. K.: The effects of organic species on the hygroscopic behaviors of inorganic aerosols, Environ. Sci. Technol., 36, 2422-2428, 2002.

Chuang, P. Y.: Measurement of the timescale of hygroscopic growth for atmospheric aerosols, J. Geophys. Res.-Atmos., 108, 4282, doi:10.1029/2002JD002757, 2003.

Cocker, D. R., Clegg, S. L., Flagan, R. C., and Seinfeld, J. H.: The effect of water on gas-particle partitioning of secondary organic aerosol. Part I: Alpha-pinene/ozone system, Atmos. Environ., 35, 6049-6072, 2001a.

Cocker, D. R., Flagan, R. C., and Seinfeld, J. H.: State-of-the-art chamber facility for studying atmospheric aerosol chemistry, Environ. Sci. Technol., 35, 2594-2601, 2001b.

Cocker, D. R., Mader, B. T., Kalberer, M., Flagan, R. C., and Seinfeld, J. H.: The effect of water on gas-particle partitioning of secondary organic aerosol: II. m-xylene and 1,3,5trimethylbenzene photooxidation systems, Atmos. Environ., 35, 6073-6085, 2001c.

Cocker, D. R., Whitlock, N. E., Flagan, R. C., and Seinfeld, J. H.: Hygroscopic properties of Pasadena, California aerosol, Aerosol Sci. Technol., 35, 637-647, 2001d.

Collins, D. R., Flagan, R. C., and Seinfeld, J. H.: Improved inversion of scanning DMA data, Aerosol Sci. Technol., 36, 1-9, 2002.

Covert, D. S. and Heintzenberg, J.: Size distributions and chemicalproperties of aerosol at Ny Alesund, Svalbard, Atmos. Environ. Part A-General Topics, 27, 2989-2997, 1993.

Cruz, C. N. and Pandis, S. N.: Deliquescence and hygroscopic 
growth of mixed inorganic-organic atmospheric aerosol, Environ. Sci. Technol., 34, 4313-4319, 2000.

DeCarlo, P., Slowik, J. G., Worsnop, D. R., Davidovits, P., and Jimenez, J. L.: Particle morphology and density characterization by combined mobility and aerodynamic diameter measurements. Part 1: theory, Aerosol Sci. Technol., 38, 1185-1205, 2004.

Ferron, G. A., Karg, E., Busch, B., and Heyder, J.: Ambient particles at an urban, semi-urban and rural site in central Europe: hygroscopic properties, Atmos. Environ., 39, 343-352, 2005.

Finlay, W. H., Stapleton, K. W., and Zuberbuhler, P.: Errors in regional lung deposition predictions of nebulized salbutamol sulphate due to neglect or partial inclusion of hygroscopic effects, Int. J. Pharm., 149, 63-72, 1997.

Gao, S., Keywood, M., Ng, N. L., Surratt, J., Varutbangkul, V., Bahreini, R., Flagan, R. C., and Seinfeld, J. H.: Low-molecularweight and oligomeric components in secondary organic aerosol from the ozonolysis of cycloalkenes and alpha-pinene, J. Phys. Chem. A, 108, 10 147-10 164, 2004a.

Gao, S., Ng, N. L., Keywood, M., Varutbangkul, V., Bahreini, R., Nenes, A., He, J. W., Yoo, K. Y., Beauchamp, J. L., Hodyss, R. P., Flagan, R. C., and Seinfeld, J. H.: Particle phase acidity and oligomer formation in secondary organic aerosol, Environ. Sci. Technol., 38, 6582-6589, 2004b.

Griffin, R. J., Cocker, D. R., Flagan, R. C., and Seinfeld, J. H.: Organic aerosol formation from the oxidation of biogenic hydrocarbons, J. Geophys. Res.-Atmos., 104, 3555-3567, 1999.

Guenther, A., Hewitt, C. N., Erickson, D., Fall, R., Geron, C., Graedel, T., Harley, P., Klinger, L., Lerdau, M., McKay, W. A., Pierce, T., Scholes, B., Steinbrecher, R., Tallamraju, R., Taylor, J., and Zimmerman, P.: A global-model of natural volatile organic-compound emissions, J. Geophys. Res.-Atmos., 100, 8873-8892, 1995.

Hansson, H. C., Rood, M. J., Koloutsou-Vakakis, S., Hameri, K., Orsini, D., and Wiedensohler, A.: $\mathrm{NaCl}$ aerosol particle hygroscopicity dependence on mixing with organic compounds, J. Atmos. Chem., 31, 321-346, 1998.

Hartz, K. E. H., Rosenorn, T., Ferchak, S. R., Raymond, T. M., Bilde, M., Donahue, N. M., and Pandis, S. N.: Cloud condensation nuclei activation of monoterpene and sesquiterpene secondary organic aerosol, J. Geophys. Res.-Atmos., 110, D14208, doi:10.1029/2004JD005754, 2005.

Heintzenberg, J., Massling, A., and Birmili, W.: The connection between hygroscopic and optical particle properties in the atmospheric aerosol, Geophys. Res. Lett., 28, 3649-3651, 2001.

Holzinger, R., Lee, A., Paw, K. T., and Goldstein, A. H.: Observations of oxidation products above a forest imply biogenic emissions of very reactive compounds, Atmos. Chem. Phys., 5, 6775, 2005, http://www.atmos-chem-phys.net/5/67/2005/.

Intergovernmental Panel on Climate Change: Climate change 2001, Cambridge University Press, Cambridge, UK, 2001.

Jacobson, M. C., Hansson, H. C., Noone, K. J., and Charlson, R. J.: Organic atmospheric aerosols: review and state of the science, Rev. Geophys., 38, 267-294, 2000.

Janson, R., Rosman, K., Karlsson, A., and Hansson, H. C.: Biogenic emissions and gaseous precursors to forest aerosols, Tellus Ser. B-Chem. Phys. Meteorol., 53, 423-440, 2001.

Jayne, J. T., Leard, D. C., Zhang, X. F., Davidovits, P., Smith, K. A., Kolb, C. E., and Worsnop, D. R.: Development of an aerosol mass spectrometer for size and composition analysis of submi- cron particles, Aerosol Sci. Technol., 33, 49-70, 2000.

Jimenez, J. L., Bahreini, R., Cocker, D. R., Zhuang, H., Varutbangkul, V., Flagan, R. C., Seinfeld, J. H., O’Dowd, C. D., and Hoffmann, T.: New particle formation from photooxidation of diiodomethane (CH2I2), J. Geophys. Res.-Atmos., 108, doi:10.1029/2002JD002452, 2003.

Kalberer, M., Paulsen, D., Sax, M., Steinbacher, M., Dommen, J., Prevot, A. S. H., Fisseha, R., Weingartner, E., Frankevich, V., Zenobi, R., and Baltensperger, U.: Identification of polymers as major components of atmospheric organic aerosols, Science, 303, 1659-1662, 2004.

Kanakidou, M., Seinfeld, J. H., Pandis, S. N., Barnes, I., Dentener, F. J., Facchini, M. C., Van Dingenen, R., Ervens, B., Nenes, A., Nielsen, C. J., Swietlicki, E., Putaud, J. P., Balkanski, Y., Fuzzi, S., Horth, J., Moortgat, G. K., Winterhalter, R., Myhre, C. E. L., Tsigaridis, K., Vignati, E., Stephanou, E. G., and Wilson, J.: Organic aerosol and global climate modelling: a review, Atmos. Chem. Phys., 5, 1053-1123, 2005, http://www.atmoschem-phys.net/5/1053/2005/.

Kavouras, I. G., Mihalopoulos, N., and Stephanou, E. G.: Formation and gas/particle partitioning of monoterpenes photooxidation products over forests, Geophys. Res. Lett., 26, 55-58, 1999a.

Kavouras, I. G., Mihalopoulos, N., and Stephanou, E. G.: Secondary organic aerosol formation vs primary organic aerosol emission: in situ evidence for the chemical coupling between monoterpene acidic photooxidation products and new particle formation over forests, Environ. Sci. Technol., 33, 1028-1037, 1999b.

Kerminen, V. M.: The effects of particle chemical character and atmospheric processes on particle hygroscopic properties, J. Aerosol Sci., 28, 121-132, 1997.

Keywood, M. D., Varutbangkul, V., Bahreini, R., Flagan, R. C., and Seinfeld, J. H.: Secondary organic aerosol formation from the ozonolysis of cycloalkenes and related compounds, Environ. Sci. Technol., 38, 4157-4164, 2004.

Khlystov, A., Stanier, C. O., Takahama, S., and Pandis, S. N.: Water content of ambient aerosol during the Pittsburgh air quality study, J. Geophys. Res.-Atmos., 110, D07S10, doi:10.1029/2004JD004651, 2005.

Kleindienst, T. E., Corse, E. W., Li, W., McIver, C. D., Conver, T. S., Edney, E. O., Driscoll, D. J., Speer, R. E., Weathers, W. S., and Tejada, S. B.: Secondary organic aerosol formation from the irradiation of simulated automobile exhaust, J. Air Waste Manage. Assoc., 52, 259-272, 2002.

Kleindienst, T. E., Smith, D. F., Li, W., Edney, E. O., Driscoll, D. J., Speer, R. E., and Weathers, W. S.: Secondary organic aerosol formation from the oxidation of aromatic hydrocarbons in the presence of dry submicron ammonium sulfate aerosol, Atmos. Environ., 33, 3669-3681, 1999.

Lee, A., Goldstein, A. H., Keywood, M. D., Gao, S., Kroll, J. H., Varutbangkul, V., Bahreini, R., Ng, N. L., Flagan, R. C., and Seinfeld, J. H.: Gas-phase products and secondary aerosol yields from the ozonolysis of ten different terpenes, J. Geophys. Res.-Atmos., 111, art. no. D07302, doi:10.1029/2005JD006437, 2006.

Li, Z. D., Williams, A. L., and Rood, M. J.: Influence of soluble surfactant properties on the activation of aerosol particles containing inorganic solute, J. Atmos. Sci., 55, 1859-1866, 1998. 
Lim, H. J. and Turpin, B. J.: Origins of primary and secondary organic aerosol in Atlanta: results of time-resolved measurements during the Atlanta supersite experiment, Environ. Sci. Technol., 36, 4489-4496, 2002.

Lindinger, W., Hansel, A., and Jordan, A.: Proton-transfer-reaction mass spectrometry (PTR-MS): On-line monitoring of volatile organic compounds at pptv levels, Chem. Soc. Rev., 27, 347-354, 1998.

Liu, B. Y. H., Pui, D. Y. H., Whitby, K. T., Kittelson, D. B., Kousaka, Y., and McKenzie, R. L.: Aerosol mobility chromatograph - new detector for sulfuric-acid aerosols, Atmos. Environ., 12, 99-104, 1978.

Massling, A., Wiedensohler, A., Busch, B., Neusüss, C., Quinn, P., Bates, T., and Covert, D.: Hygroscopic properties of different aerosol types over the Atlantic and Indian oceans, Atmos. Chem. Phys., 3, 1377-1397, 2003, http://www.atmos-chemphys.net/3/1377/2003/.

McMurry, P. H. and Stolzenburg, M. R.: On the sensitivity of particle-size to relative-humidity for Los Angeles aerosols, Atmos. Environ., 23, 497-507, 1989.

Nenes, A., Pandis, S. N., and Pilinis, C.: ISORROPIA: A new thermodynamic equilibrium model for multiphase multicomponent inorganic aerosols, Aquat. Geochem., 4, 123-152, 1998.

Pio, C., Alves, C., and Duarte, A.: Organic components of aerosols in a forested area of central Greece, Atmos. Environ., 35, 389401, 2001.

Prenni, A. J., De Mott, P. J., and Kreidenweis, S. M.: Water uptake of internally mixed particles containing ammonium sulfate and dicarboxylic acids, Atmos. Environ., 37, 4243-4251, 2003.

Quinn, P. K., Bates, T. S., Baynard, T., Clarke, A. D., Onasch, T. B., Wang, W., Rood, M. J., Andrews, E., Allan, J., Carrico, C. M., Coffman, D., and Worsnop, D.: Impact of particulate organic matter on the relative humidity dependence of light scattering: A simplified parameterization, Geophys. Res. Lett., 32, L22809, doi:10.1029/2005GL024322, 2005.

Rader, D. J. and McMurry, P. H.: Application of the tandem differential mobility analyzer to studies of droplet growth or evaporation, J. Aerosol Sci., 17, 771-787, 1986.

Saathoff, H., Naumann, K. H., Schnaiter, M., Schock, W., Mohler, O., Schurath, U., Weingartner, E., Gysel, M., and Baltensperger, U.: Coating of soot and $\left(\mathrm{NH}_{4}\right)_{2} \mathrm{SO}_{4}$ particles by ozonolysis products of alpha-pinene, J. Aerosol Sci., 34, 1297-1321, 2003.

Saxena, P., Hildemann, L. M., McMurry, P. H., and Seinfeld, J. H.: Organics alter hygroscopic behavior of atmospheric particles, J. Geophys. Res.-Atmos., 100, 18 755-18 770, 1995.

Seinfeld, J. H. and Pandis, S. N.: Atmospheric chemistry and physics, John Wiley \& Sons, Inc., 1998.

Sellegri, K., Hanke, M., Umann, B., Arnold, F., and Kulmala, M.: Measurements of organic gases during aerosol formation events in the boreal forest atmosphere during QUEST, Atmos. Chem. Phys., 5, 373-384, 2005, http://www.atmos-chemphys.net/5/373/2005/.

Simpson, D., Winiwarter, W., Borjesson, G., Cinderby, S., Ferreiro, A., Guenther, A., Hewitt, C. N., Janson, R., Khalil, M. A. K., Owen, S., Pierce, T. E., Puxbaum, H., Shearer, M., Skiba, U., Steinbrecher, R., Tarrason, L., and Oquist, M. G.: Inventorying emissions from nature in Europe, J. Geophys. Res.-Atmos., 104, 8113-8152, 1999.

Stokes, R. H. and Robinson, R. A.: Interactions in aqueous nonelec- trolyte solutions. I. Solute-solvent equilibria, J. Phys. Chem., 70, 2126-2131, 1966.

Svenningsson, I. B., Hansson, H. C., Wiedensohler, A., Ogren, J. A., Noone, K. J., and Hallberg, A.: Hygroscopic growth of aerosol-particles in the Po Valley, Tellus Ser. B-Chem. Phys. Meteorol., 44, 556-569, 1992.

Swietlicki, E., Zhou, J. C., Berg, O. H., Martinsson, B. G., Frank, G., Cederfelt, S. I., Dusek, U., Berner, A., Birmili, W., Wiedensohler, A., Yuskiewicz, B., and Bower, K. N.: A closure study of sub-micrometer aerosol particle hygroscopic behaviour, Atmos. Res., 50, 205-240, 1999.

Swietlicki, E., Zhou, J. C., Covert, D. S., Hameri, K., Busch, B., Vakeva, M., Dusek, U., Berg, O. H., Wiedensohler, A., Aalto, P., Makela, J., Martinsson, B. G., Papaspiropoulos, G., Mentes, B., Frank, G., and Stratmann, F.: Hygroscopic properties of aerosol particles in the northeastern Atlantic during ACE-2, Tellus Ser. B-Chem. Phys. Meteorol., 52, 201-227, 2000.

Tang, I. N.: Water transformation and growth of aerosol particles composed of mixed salts, J. Aerosol Sci., 361-371, 1976.

Tang, I. N. and Munkelwitz, H. R.: Water activities, densities, and refractive-indexes of aqueous sulfates and sodium-nitrate droplets of atmospheric importance, J. Geophys. Res.-Atmos., 99, 18 801-18 808, 1994.

Turpin, B. J., Huntzicker, J. J., Larson, S. M., and Cass, G. R.: Los Angeles summer midday particulate carbon - primary and secondary aerosol, Environ. Sci. Technol., 25, 1788-1793, 1991.

VanReken, T. M., Ng, N. L., Flagan, R. C., and Seinfeld, J. H.: Cloud condensation nucleus activation properties of biogenic secondary organic aerosol, J. Geophys. Res.-Atmos., 110, D07206, doi:10.1029/2004JD005465, 2005.

Virkkula, A., Van Dingenen, R., Raes, F., and Hjorth, J.: Hygroscopic properties of aerosol formed by oxidation of limonene, alpha-pinene, and beta-pinene, J. Geophys. Res.-Atmos., 104, 3569-3579, 1999.

Wang, S. C. and Flagan, R. C.: Scanning electrical mobility spectrometer, Aerosol Sci. Technol., 13, 230-240, 1990.

Weis, D. D. and Ewing, G. E.: Water content and morphology of sodium chloride aerosol particles, J. Geophys. Res.-Atmos., 104, $21275-21285,1999$.

Wiedensohler, A.: An approximation of the bipolar chargedistribution for particles in the sub-micron size range, J. Aerosol Sci., 19, 387-389, 1988.

Wise, M. E., Surratt, J. D., Curtis, D. B., Shilling, J. E., and Tolbert, M. A.: Hygroscopic growth of ammonium sulfate/dicarboxylic acids, J. Geophys. Res.-Atmos., 108, 4638, doi:10.1029/2003JD003775, 2003.

Xiong, J. Q., Zhong, M. H., Fang, C. P., Chen, L. C., and Lippmann, M.: Influence of organic films on the hygroscopicity of ultrafine sulfuric acid aerosol, Environ. Sci. Technol., 32, 35363541, 1998.

Yu, J. Z., Griffin, R. J., Cocker, D. R., Flagan, R. C., Seinfeld, J. H., and Blanchard, P.: Observation of gaseous and particulate products of monoterpene oxidation in forest atmospheres, Geophys. Res. Lett., 26, 1145-1148, 1999.

Zhang, X. Q., McMurry, P. H., Hering, S. V., and Casuccio, G. S.: Mixing characteristics and water-content of submicron aerosols measured in Los Angeles and at the Grand Canyon, Atmos. Environ. Part A-General Topics, 27, 1593-1607, 1993. 